\title{
Experimental investigations into the mechanical behaviour of the breccias around the proposed Gibraltar Strait tunnel
}

\section{Journal Article}

Author(s):

Dong, Weijie; Pimentel, Erich; Anagnostou, Georg

Publication date:

2013

Permanent link:

https://doi.org/10.3929/ethz-b-000059372

Rights / license:

In Copyright - Non-Commercial Use Permitted

Originally published in:

Rock Mechanics and Rock Engineering 46(5), https://doi.org/10.1007/s00603-012-0350-y 


\title{
Experimental Investigations into the Mechanical Behaviour of the Breccias Around the Proposed Gibraltar Strait Tunnel
}

\author{
W. Dong $\cdot$ E. Pimentel $\cdot$ G. Anagnostou
}

Received: 1 August 2012/Accepted: 6 December 2012/Published online: 11 January 2013

(C) Springer-Verlag Wien 2013

\begin{abstract}
The proposed Gibraltar Strait tunnel will cross two zones with breccia consisting of a chaotic mixture of blocks and stones embedded in a clay matrix. The breccia is saturated, has a high porosity and exhibits poor mechanical properties in the range between hard soils and weak rocks. The overburden and high in situ pore pressures in combination with the low strength of the breccia may lead to heavy squeezing. The crossing of the breccia zones thus represents one of the key challenges in the construction of the tunnel. In order to improve our understanding of the mechanical behaviour of the breccias, a series of triaxial compressions tests were carried out. Standard rock mechanics test equipment was not adequate for this purpose, because it does not provide pore pressure control, which is important in the case of saturated porous materials. Pore pressure control is routine in soil mechanics tests, but standard soil mechanics equipment allows only for relatively low nominal loads and pressures. In addition, the low hydraulic conductivity of the breccias demands extremely low loading rates and a long test duration. For these reasons, we re-designed several components of the test apparatus to investigate the mechanical behaviour of the breccia by means of consolidated drained and undrained tests. The tests provided important results concerning the strength, volumetric behaviour, consolidation state and hydraulic conductivity of the breccias. The present paper describes the test equipment and procedures, provides an overview of the test results and discusses features of the mechanical behaviour of the breccias which make them qualitatively different from other weak rocks such as kakirites-a typical squeezing rock in alpine
\end{abstract}

W. Dong · E. Pimentel $(\varangle) \cdot$ G. Anagnostou

ETH Zurich, Zurich, Switzerland

e-mail: erich.pimentel@igt.baug.ethz.ch tunnelling. The paper also demonstrates the practical importance of the experimental findings for tunnelling in general. More specifically, it investigates the short-term ground response to tunnel excavation from the perspective of elasto-plastic behaviour with the Mohr-Coulomb yield criterion. The computational results indicate that the breccias will probably experience very large deformations already around the advancing tunnel heading, which can be reduced considerably, however, by advance drainage. The analyses additionally show that plastic dilatancy is favourable with respect to the short-term response, thus highlighting the importance of the constitutive model when it comes to theoretical predictions.

Keywords Triaxial test - Pore pressure - Breccia . Gibraltar Strait tunnel · Squeezing ground .

Ground response

\section{List of symbols}

A Pore pressure parameter $A$

a Tunnel radius

$A_{\mathrm{f}} \quad$ Pore pressure parameter $A$ at failure

$B \quad$ Pore pressure parameter $B$

$C_{\mathrm{s}} \quad$ Compressibility of specimen skeleton

$c^{\prime} \quad$ Effective cohesion of ground

$c_{\mathrm{v}} \quad$ Coefficient of consolidation

$C_{\mathrm{w}} \quad$ Compressibility of water

$D \quad$ Diameter of sample

$D_{\text {o }} \quad$ Diameter of the oil pressure amplifier cylinder

$D_{\mathrm{p}} \quad$ Diameter of the axial loading piston

$D_{\mathrm{w}} \quad$ Diameter of the pore water pressure device cylinder

E Young's modulus

$H \quad$ Height of sample

$k \quad$ Hydraulic conductivity

$n \quad$ Porosity 
$p_{\mathrm{w}} \quad$ Pore pressure

$p^{\prime} \quad$ Effective isotropic stress

$p_{\mathrm{w}, 0} \quad$ Initial pore pressure

$q^{\prime} \quad$ Effective deviatoric stress

$s_{\mathrm{u}} \quad$ Undrained shear strength

$T$ Temperature

$t \quad$ Time

$t_{\mathrm{f}} \quad$ Time taken to reach $95 \%$ dissipation of excess pore pressure at failure

$u_{\mathrm{a}} \quad$ Tunnel wall displacement

$V_{\mathrm{o}} \quad$ Volume of oil in triaxial system

$V_{\mathrm{s}} \quad$ Volume of specimen

$V_{\mathrm{w}} \quad$ Volume of water in triaxial system

$w \quad$ Water content

$z \quad$ Coordinate in vertical direction

\section{Greek symbols}

$\alpha_{\mathrm{o}} \quad$ Thermal expansion coefficient of oil

$\alpha_{\mathrm{w}} \quad$ Thermal expansion coefficient of water

$\gamma_{\mathrm{w}} \quad$ Unit weight of water

$\Delta h_{\mathrm{o}} \quad$ Displacement of the cylinder of the oil pressure amplifier

$\Delta h_{\mathrm{o}}^{\text {temp }}$ Temperature induced displacement of the cylinder of the oil pressure amplifier

$\Delta h_{\mathrm{p}} \quad$ Displacement of the axial loading piston

$\Delta h_{\mathrm{w}} \quad$ Displacement of the cylinder of the pore water pressure device

$\Delta h_{\mathrm{w}}^{\text {temp }}$ Temperature induced displacement of the cylinder of the pore water pressure device

$\Delta p_{\mathrm{w}} \quad$ Increment of pore pressure

$\Delta \sigma_{1} \quad$ Increment of axial stress

$\Delta \sigma_{3} \quad$ Increment of radial stress

$\Delta T \quad$ Temperature change

$\varepsilon_{1} \quad$ Axial strain

$\varepsilon_{\mathrm{vol}} \quad$ Volumetric strain

$\varepsilon_{\mathrm{vol}}^{\mathrm{o}} \quad$ Volumetric strain (determined via oil volume change)

$\varepsilon_{\text {vol }}^{\text {o,corr }} \quad$ Volumetric strain (corrected via oil volume change)

$\varepsilon_{\mathrm{vol}}^{\text {o,err }} \quad$ Temperature induced volumetric strain error (via oil volume change)

$\varepsilon_{\mathrm{vol}}^{\mathrm{w}} \quad$ Volumetric strain (determined via water volume change)

$\varepsilon_{\mathrm{vol}}^{\mathrm{w}, \mathrm{corr}}$ Volumetric strain (corrected via water volume change)

$\varepsilon_{\mathrm{vol}}^{\mathrm{w}, \mathrm{err}} \quad$ Temperature induced volumetric strain error (via water volume change)

$\eta \quad$ Constant depending on the drainage conditions

$v \quad$ Poisson's ratio

$\sigma \quad$ Total stress

$\sigma_{1} \quad$ Axial stress

$\sigma_{3} \quad$ Radial stress

$\sigma^{\prime} \quad$ Effective stress $\sigma_{0}^{\prime} \quad$ Initial effective stress

$\sigma_{1}^{\prime} \quad$ Effective axial stress

$\sigma_{3}^{\prime} \quad$ Effective radial stress

$\sigma_{\mathrm{a}, \mathrm{DR}}^{\prime} \quad$ Effective stress after advance drainage

$\sigma_{0} \quad$ Initial total stress

$\sigma_{\mathrm{a}} \quad$ Support pressure at excavation boundary

$\sigma_{\mathrm{a}, \mathrm{DR}} \quad$ Total stress after advance drainage

$\phi^{\prime} \quad$ Effective friction angle

$\psi \quad$ Dilatancy angle

\section{Introduction}

The proposed Gibraltar Strait link consists of a subaqueous tunnel that will cross, among other formations, two paleochannels filled with clayey breccias of extremely poor quality (Figs. 1, 2). The breccias consist of a chaotic mixture of blocks, stones and stone splinters embedded in a clay matrix, which exhibits low strength and high deformability (Pliego 2005). The mechanical behaviour of the breccias lies in the range between stiff clay and weak rock. They represent the weakest material in tunnel lithology. On account of the in situ pore pressures and stresses associated with the depth of the alignment (maximum $300 \mathrm{~m}$ below sea bed and $600 \mathrm{~m}$ below sea level), the breccias are expected to be highly susceptible to squeezing (Lombardi et al. 2009). Squeezing is the phenomenon of large deformations around the opening. The ground pressure developing when attempting to prevent these deformations by

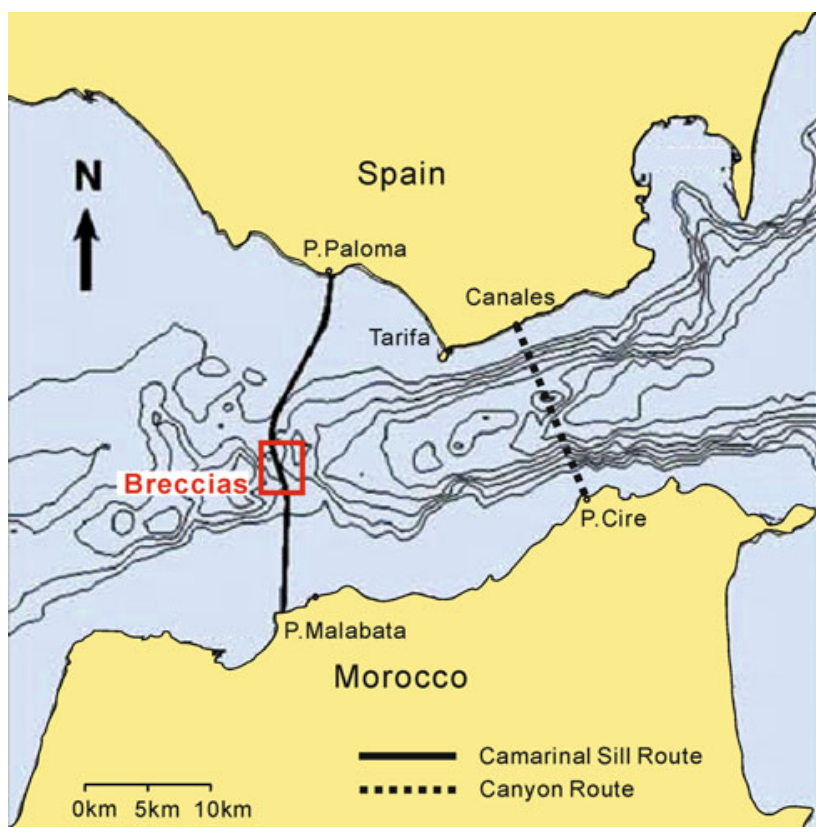

Fig. 1 Map of Gibraltar Strait with the two alternative routes and location of the breccia zones (after Sandoval et al. 2011) 
installing a stiff tunnel support may endanger its structural safety. Squeezing is a recognized problem in tunnelling through poor quality ground. It has been observed, for example, during the construction of the subaqueous Seikan tunnel in Japan (Hashimoto and Tanabe 1986) and in several alpine tunnels, such as the Gotthard motorway tunnel, the Simplon tunnel and, more recently, the Gotthard Base Tunnel (Kovári et al. 2000) and the access gallery of the planned Lyon-Turin Base Tunnel (Triclot et al. 2007; Bonini and Barla 2012). The expected squeezing behaviour of the breccias, together with the limited options and difficult conditions in terms of accessibility for pre-exploration or pre-treatment of the ground, makes overcoming the breccias one of the key challenges of the Gibraltar Strait project and it has motivated a considerable number of field, laboratory and desktop investigations (see Sect. 2 of the present paper).

The intensity of the squeezing depends essentially on the strength and stiffness of the ground. The mechanical behaviour of the ground is usually investigated by means of triaxial compression tests. Due to the saturated state of the breccia and due to the decisive effect of the clay matrix on its behaviour, the effect of pore pressure should be considered in planning and executing the tests and in the interpretation of their results (based on the principle of effective stresses). The standard test apparatus from soil mechanics or rock mechanics are, however, not adequate for testing this material. Soil mechanics equipment handles only low nominal loads and pressures, while rock mechanics equipment does not provide monitoring or control of the pore pressure. Overcoming these limitations calls for several modifications of the triaxial test apparatus. Such adaptations have been described by Steiger and Leung (1991), Aristorenas (1992), Bellwald (1992), Bonini et al. (2009) and Barla et al. (2010), and have been implemented by our laboratory in previous experimental work within the scope of investigations into the kakirites in the Gotthard Base Tunnel (Vogelhuber and Kovári 1998, 2000; Vogelhuber et al. 2004a, b; Vogelhuber 2007). The Gibraltar breccias present additional experimental difficulties in relation to their low permeability, which demands extremely low loading rates and long test durations (cf. Sect. 4.1 of the present paper). One of the main objectives of the present paper is thus to explain features and procedures that are key to the implementation of the triaxial test technique on weak and very low permeability rocks under high stress (Sect. 3).

As experimental results have been published for various weak rocks (such as clayshale or kakirites) but not for breccias, a second objective of this paper is to discuss the mechanical behaviour of the breccias under triaxial test conditions and to highlight some distinguishing characteristics of the Gibraltar breccias (Sect. 4). Finally, Sect. 5 of the paper illustrates the significance of the material behaviour under investigation for practical tunnel engineering by analyzing the short-term ground response to tunnelling with reference to the experimental results.

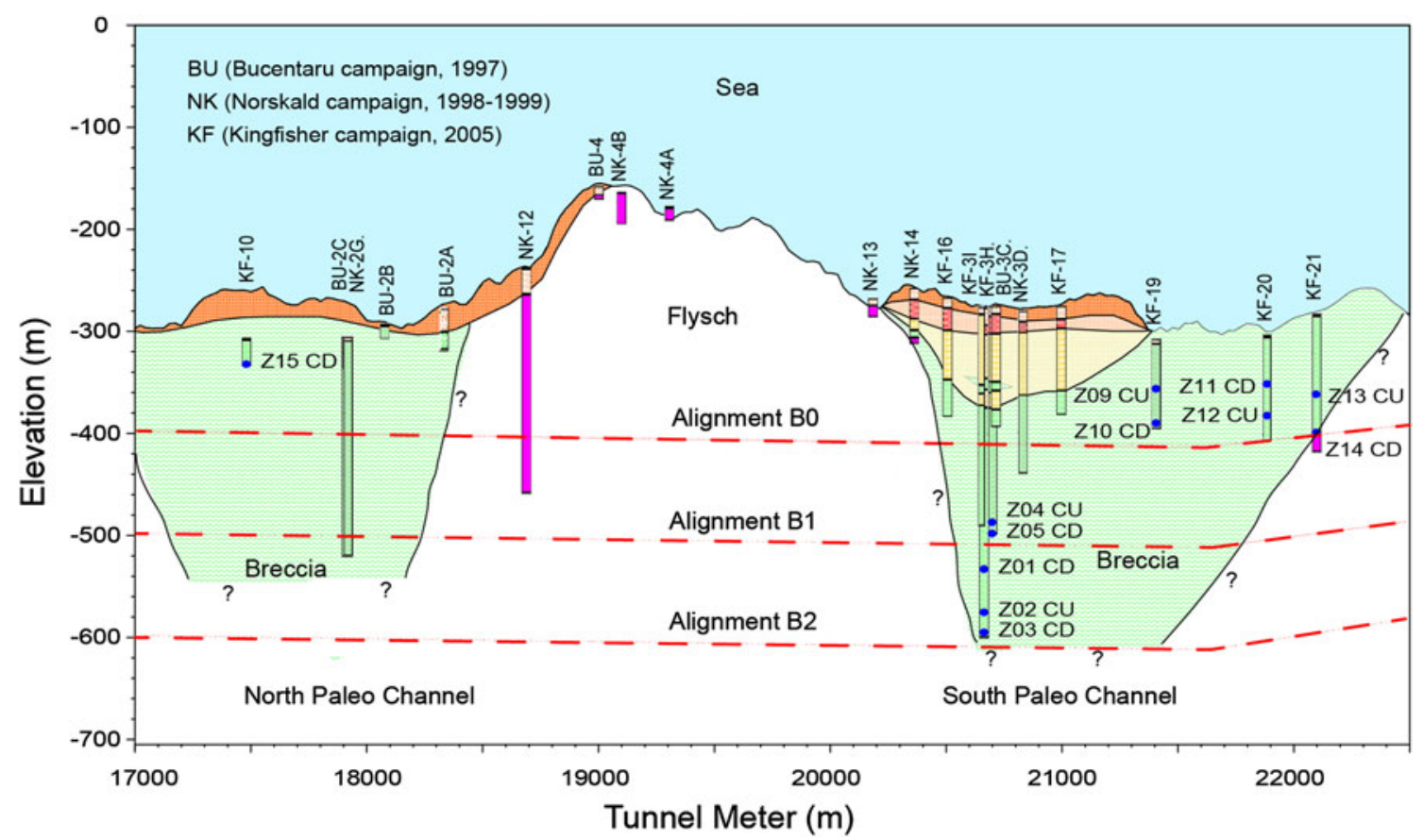

Fig. 2 Geological profile of central part of the planned tunnel with the two breccia zones, and basic alternative vertical alignments and location of the exploratory boreholes and samples (after Bahmad 2008) 


\section{Background}

\subsection{Project Description}

The Gibraltar Strait connects the Atlantic Ocean with the Mediterranean Sea and thus separates Europe from Africa. The strait is one of the busiest sea lanes in the world. The conditions for ships crossing the strait are often difficult already and will worsen over time. A permanent link across the straits will therefore provide a more reliable and higher capacity transport connection between south-west Europe and north-west Africa. Under a bilateral cooperation agreement of 1980, the governments of Spain and Morocco have been jointly studying the feasibility of a fixed link across the Gibraltar Strait. Two companies were set up to lead the project, namely Société Nationale d'Etude du Détroit (SNED) and Sociedad Española de Estudios para la Comunicación Fija a través del Estrecho de Gibraltar, S.A. (SECEGSA) in Morocco and Spain, respectively.

Figure 1 shows the map of the Gibraltar Strait and two alternative horizontal alignments. Following topographical studies, the so-called "Canyon Route" was discarded. Although it was the route with the shortest coast to coast distance, the maximum water depth along the route is more than $800 \mathrm{~m}$. That would increase the technical difficulties and result in very long stretches beneath both continents in the case of a tunnel solution (or a bridge with a maximum free span of $14 \mathrm{~km}$ ). The route selected for the fixed link is the "Camarinal Sill Route" (Fig. 1). It has a maximum sea depth of $300 \mathrm{~m}$ and a coast to coast distance of about $28 \mathrm{~km}$.

The Camarinal Sill Route offered the option of a bridge or a tunnel. After comparing these two options, the tunnel solution was selected for further study. The major limitations and disadvantages of a bridge were summarized by Pliego (2005) as follows: interference with maritime traffic in the strait, lack of technological experience, temporary restrictions on operation due to weather conditions (decreasing the cost-effectiveness of the fixed link), and finally the higher safety risk of a bridge which is an increasingly important aspect in the last decade.

\subsection{Exploration Campaigns}

Since 1980 several on- and off-shore exploratory campaigns have been carried out. The first campaigns focused more on the collection of geodetic, topographic and tectonic data, while the main tasks of the more recent campaigns concerned sea currents and geotechnical data from the relevant formations (Sandoval et al. 2011). Two shafts (Bolonia and Malabata shaft) at each terminal of the planned tunnel, together with the Tarifa exploratory gallery in the north, were excavated on-shore.
The study of sea currents and the production of a reliable forecasting method (University of Cadiz and SECEGSA) were prerequisites for starting the demanding offshore drilling and core recovery operation (Sandoval et al. 2011). The sea current regime is governed by the temperature and salinity gradient between the Atlantic Ocean and the Mediterranean Sea as well by intertidal currents. The water velocity profile therefore changes depending on the location, time and depth. The maximum water speed can exceed $3 \mathrm{~m} / \mathrm{s}$ (6 knots), which in combination with the considerable sea depth of $300 \mathrm{~m}$ may cause inadmissible twisting and bending stresses in the rods used for drilling exploratory boreholes off-shore. Drilling operations are therefore possible only during relatively short periods, when the water speed is forecast to be $<1.7 \mathrm{~m} / \mathrm{s}$ (3.3 knots). Since these periods are too short for drilling a deep borehole, interruptions to drilling operations and temporary departures from the drilling location (involving core recovery and difficult restarts of drilling at a later time) are unavoidable. In addition to the problems with sea currents, interference from sea traffic makes the off-shore exploratory campaigns particularly difficult.

According to the exploratory work carried out before 1996, flysch forms the main lithology of the route. The original vertical alignment was about $100 \mathrm{~m}$ below the seabed (vertical alignment B0 in Fig. 2). Since 1997, however, three additional off-shore deep drilling exploratory campaigns with core recovery have been carried out. In the so-called Bucentaur campaign of 1997, bioclastic sand was detected in the first $100 \mathrm{~m}$ beneath the seabed in the central part of the route. As a consequence, a deeper tunnel alignment was chosen. The tunnel depth in this area was increased from 100 to $200 \mathrm{~m}$ below the seabed (vertical alignment $B 1$ in Fig. 2).

In the so-called Norskald campaign from 1998 to 1999, the two paleo-channels in the middle of the strait were detected. They are filled with weak breccias and their depth was initially estimated to be about $200 \mathrm{~m}$ below the seabed. Pliego (2005) explained the formation of the two channels and the presence of the breccias in terms of erosive action followed by the violent submarine collapse of the flysches. According to more recent research by Luján et al. (2011), it seems that the two paleo-channels were generated by faulting and tectonic forces. After that, a major submarine landslide (the so-called Tarifa landslide) occurred and the channels were filled by breccias originating from the northeast of the Camarinal Sill. Strong marine erosion is thought to have occurred due to the transfer of water between the Atlantic Ocean and the Mediterranean Sea at the end of the Messinian Salinity Crisis, about 5.3 million or more years ago.

In order to avoid crossing the breccias, a deeper alignment (B2 in Fig. 2) was considered and thus the depth 
increased to $300 \mathrm{~m}$ below the seabed. The so-called Kingfisher campaign of 2005 had the aim of exploring, among other things, the lateral extent and depth of the breccia. The campaign consisted of 15 boreholes with a maximum depth of $300 \mathrm{~m}$ below the seabed. Many of the boreholes, including the deepest one (KF3I in Fig. 2), did not reach the flysch formation under the breccias. Consequently, the depth of the paleo-channels is still unknown today. As a deeper tunnel alignment would increase tunnel length greatly, crossing the breccias during tunnelling was considered inevitable. Alignment $B 1$ (Fig. 2) was, therefore, reconsidered in the design. This alignment is up to $200 \mathrm{~m}$ below the seabed and $500 \mathrm{~m}$ below sea level.

Figure 2 shows the location of the boreholes and of the samples selected for the test programme. The sampling equipment used during the off-shore campaigns was a wireline system with a double tube sampler with a core diameter of 59.5-63.7 $\mathrm{mm}$. The cores obtained from the boreholes of all the exploratory campaigns were stored in the Tarifa gallery under practically constant climatic conditions (100\% relative humidity, room temperature of about $\left.21{ }^{\circ} \mathrm{C}\right)$. Some of the samples were wrapped with plastic foil to better protect them from drying out (Fig. 3). These samples will be referred to as "protected" samples (as opposed to the other "unprotected" samples).

\subsection{Previous Geotechnical Investigations}

The geotechnical investigations for the Gibraltar project started more than 30 years ago. The goals varied depending on the state of knowledge and on the questions that arose after each campaign. Villanueva and Serrano (1986) described the state of the on-shore investigations in the early stages of the project. Taik and Serrano (1991) described the general concept of the tunnel project and the tunnel profile. Pliego (2005) summarized project progress, emphasizing the geologic-geotechnical environment. He also pointed out that the breccias are about $30 \%$ weaker than weak flysches, but as impervious as the flysches themselves (hydraulic conductivity $k=10^{-10} \mathrm{~m} / \mathrm{s}$ ). The Centro de Estudios y Experimentación de Obras Públicas (CEDEX) in Spain and Laboratoire Public d'Essais et d'Etudes (LPEE) in Morocco tested the index properties of breccias from off-shore boreholes Norskald and ran totally 45 triaxial tests with a radial pressure of $1-6 \mathrm{MPa}$ and a backpressure of $4 \mathrm{MPa}$. The hydraulic conductivity was reported to be around $10^{-10} \mathrm{~m} / \mathrm{s}$, the effective cohesion $c^{\prime}<0.2 \mathrm{MPa}$ and the effective friction angle $\phi^{\prime}$ between $13^{\circ}$ and $17^{\circ}$ (Pliego 2005).

The breccias represent the weakest material along the foreseen tunnel alignment. In addition, the tunnel will cross them at the deepest point below sea level and far away from the coast, i.e. in the worst possible location. For these reasons, the breccias are a key factor in the selection of the construction method and even for the technical feasibility of the project. In view of their significance, more detailed investigations into their mechanical behaviour were considered necessary. Within the framework of a research cooperation with SNED and SECEGSA on the geomechanics of subsea tunnels, the ETH Zurich investigated the strength and deformability of the breccias under triaxial test conditions. A total of 12 tests were performed from 2008 to 2010.

\section{Laboratory Investigations}

\subsection{Appearance of Breccias and Selection of Samples}

The test material comes from the cores obtained from the last two off-shore exploratory campaigns (the so-called Norskald and Kingfisher campaigns). As mentioned above, the breccias consist of a chaotic mixture of blocks, stones and stone splinters embedded in a clay matrix. Figure 4 shows the cross section of a typical breccia sample. The hard inclusions are clearly visible inside the sample. Unlike some rock specimens, neither cracks nor joints can be found on the sample surface. The results of grain size

Fig. 3 Typical breccia core

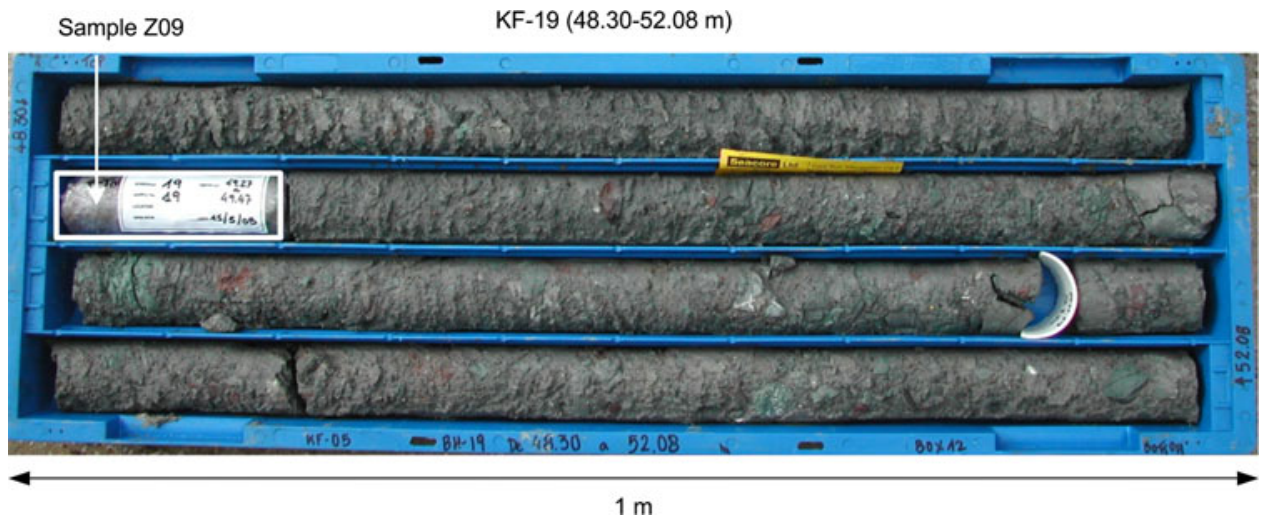




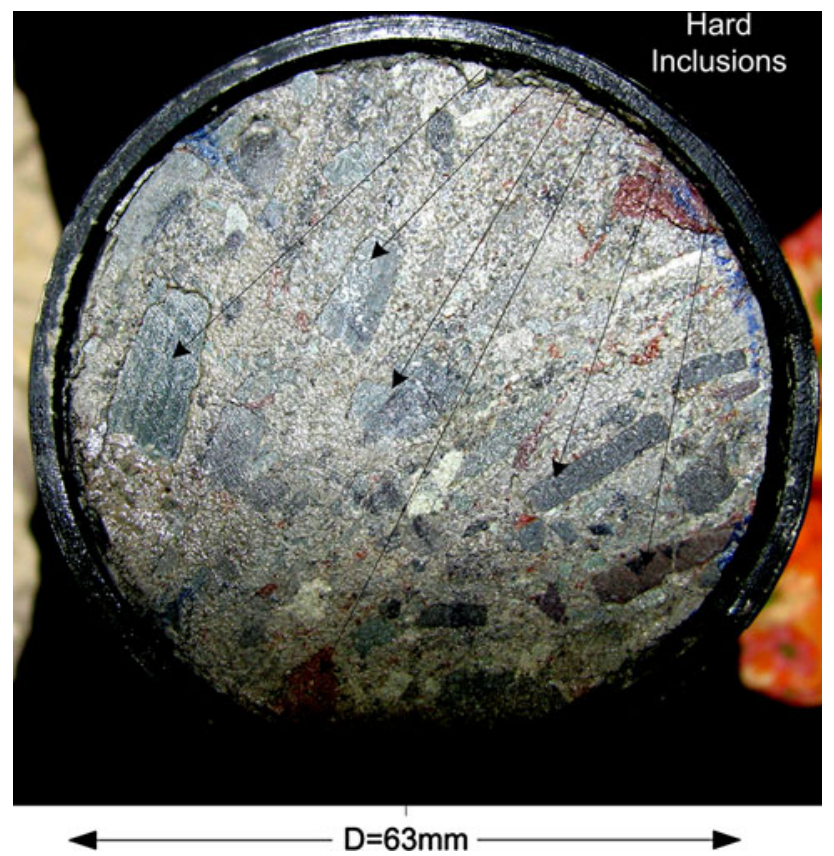

Fig. 4 Cross section of breccia core Z10

analyses indicate that the main constituents of the breccias are silt and clay, with a content of more than $80 \%$ (Fig. 5). The breccia samples can be indented by thumbnail and peeled by knife. Therefore, according to the soil and rock strength classification from field indices suggested by ISRM (1978), the samples can be classified as stiff clay or weak rock. Table 1 shows the soil index properties and Atterberg limits of a typical protected sample. The breccias are similar to stiff, fine-grained soils (Vallejo and Ferrer 2009). The plasticity index of $27 \%$ and activity of 0.77 correspond to inactive clays with high plasticity. Due to the subaqueous geological environment, the samples are $100 \%$ saturated. The saturation degree after test was calculated based on the water content $w$, the total unit weight $\gamma$ and the unit weight of the solid constituents $\gamma_{\mathrm{s}}$. The saturation degrees are slightly lower than $100 \%$ (Table 1), which can be attributed to a little drying during sampling and provisional storage on the ship or to transportation and storage in the Tarifa Gallery and to the fact that not all lost water content could be re-established during the test.

The samples for testing were selected based on the following criteria: the samples should not contain hard inclusions bigger than $1 \mathrm{~cm}$; protected samples are preferred; samples from both paleo-channels and from different depths should be tested. In addition, some unprotected samples were taken to check whether it is possible to re-establish the original water content without affecting the mechanical behaviour. Since the majority of the samples were unprotected, this would make more representative test material available for later investigations. Figure 2 shows the location of the selected samples.

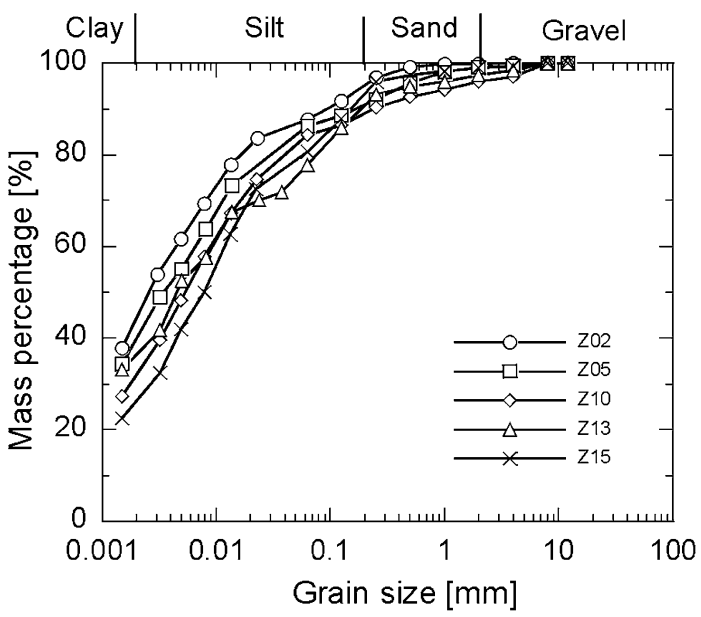

Fig. 5 Grain size distribution in breccia samples

Table 1 Index properties of breccia sample Z05 after testing

\begin{tabular}{lll}
\hline Property & Value & Units \\
\hline Total unit weight & 21.52 & $\mathrm{kN} / \mathrm{m}^{3}$ \\
Water content & 17 & $\%$ \\
Dry unit weight & 18.42 & $\mathrm{kN} / \mathrm{m}^{3}$ \\
Unit weight of solid constituents & 27.30 & $\mathrm{kN} / \mathrm{m}^{3}$ \\
Porosity & 32 & $\%$ \\
Degree of saturation & 95 & $\%$ \\
Void ratio & 0.48 & - \\
Liquid limit & 49 & $\%$ \\
Plastic limit & 22 & $\%$ \\
Plasticity index & 27 & $\%$ \\
Activity & 0.77 & - \\
\hline
\end{tabular}

The selected samples were wrapped in plastic and aluminium foil, sealed with a wax-paraffin mixture and transported to the rock mechanics laboratory of the ETH Zurich for further processing.

\subsection{Testing Devices}

The goal of the test program was to obtain representative results for the evaluation of the mechanical behaviours of breccias. The samples therefore had to be tested under conditions that were as close as possible to the in situ conditions, i.e. in a saturated state and under high radial pressures. The high pressures suggested the use of rock mechanics apparatus such as the triaxial cell of Franklin and Hoeck (1970) in combination with a stiff test frame allowing for high nominal loads. The main disadvantage of conventional test equipment is that the pore pressure can neither be controlled nor measured. This is, however, indispensable in the present case because the breccia is a saturated porous medium obeying the principle of effective 
stress (Terzaghi 1943). In addition, conventional rock mechanics test equipment does not usually allow low loading rates or the measurement of volumetric strains.

Soil mechanics test apparatus can be used for testing under controlled pore water conditions (Bishop and Henkel 1957). The main limitations are the low nominal loads, radial pressures (usually $<1 \mathrm{MPa}$ ) and pore pressures (usually $<0.2 \mathrm{MPa}$ ). Since the in situ pressures are more than one order of magnitude higher than this, it was necessary to upgrade the rock mechanics equipment with some of the capabilities of soil mechanics apparatus.

Some modifications to test techniques and equipment had already been undertaken by our laboratory in the 1990s, during the exploratory phase of the Gotthard Base Tunnel, to investigate the behaviour of kakirites (Vogelhuber 2007). The test system used for these investigations consisted of a stiff servo-controlled reaction frame with a nominal load of $600 \mathrm{kN}$ and a pressure amplifier that is also servo-controlled and able to generate radial pressures of up to $70 \mathrm{MPa}$ (Fig. 6). A triaxial cell providing pore pressure control and radial pressures of up to $28 \mathrm{MPa}$ was designed and built by our workshop. Figure 6 provides an overview of the test equipment.

Later, within the framework of further investigations during the construction of the Gotthard Base Tunnel, the control system was replaced by a modern, fast and fully digital system enabling more accurate test control at low strain rates. Hydraulic conductivity is a key parameter both for laboratory investigations (as it governs test duration) and tunnel construction (as it is decisive for the feasibility of advance drainage). In order to increase the accuracy of hydraulic conductivity measurements, as well as the reliability of pore water control during testing, the initial pore water device, which was controlled mechanically by air pressure, was replaced by a remotely controlled electromechanical device. The latter consists of a step motor, a gear, a screw that is free from backlash, and a cylinder filled with water (referred to as "water pressure cylinder", see Fig. 6 right), which is connected to the bottom of the cell. The displacement of the cylinder filled with water ( $\Delta h_{\mathrm{w}}$, see Fig. 6) is measured. This allows for determining the water flux during testing and thus for determination of the hydraulic conductivity after the water flux reaches a stationary state, i.e. when the water inflow equals to the water outflow. The water outlet of the cell can be connected either to a recipient on a scale for measuring the flux of water under atmospheric conditions (for checking whether the stationary state has been reached) or with the cylinder filled with water for applying a backpressure or a constant pore pressure of up to $2.5 \mathrm{MPa}$.

\subsection{Preparation of the Samples}

Due to the constitution and structure of the samples (hard particles embedded in a relatively soft clay matrix), specimen preparation is very demanding. The samples were cut on an electronically controlled diamond band saw (model DRAMET BS270 XY), which is used in the industry for cutting, e.g. filters, catalysators, sealings, glass and plastinates. The saw consists of a continuous metal band with diamonds both on its cutting edge and on its lateral sides (for polishing while cutting). For the breccias, a band

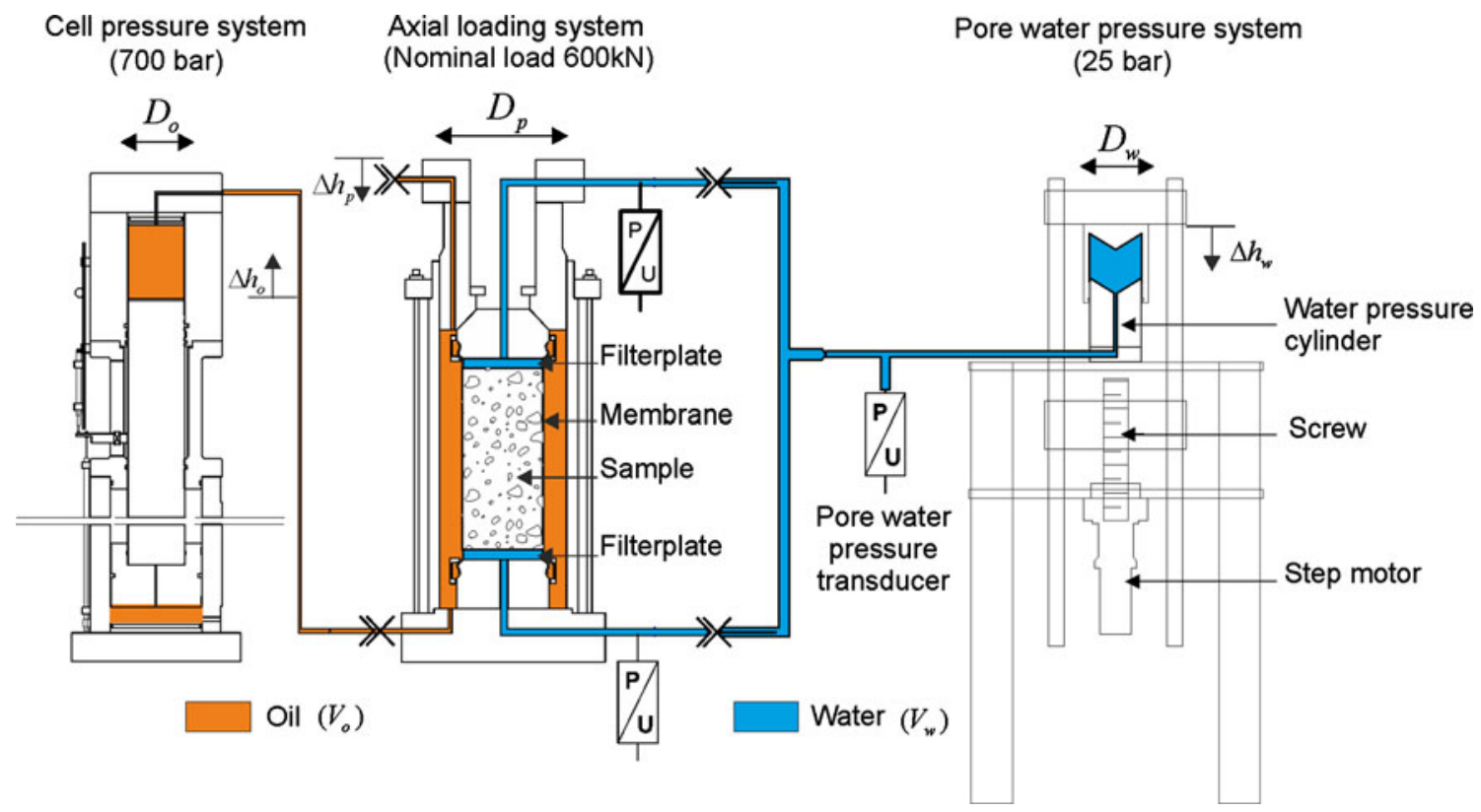

Fig. 6 Overview of the test equipment 
studded with diamonds sized from 126 to $181 \mu \mathrm{m}$ and with a total thickness of $0.7 \mathrm{~mm}$ was used. The band rotates with a linear speed of about $1,200 \mathrm{~m} / \mathrm{min}$ and can be operated in either air- or water-flushed modes. The sample is fixed with a prismatic adapter on a table, which moves towards the rotating band saw at a constant speed of minimum $4 \mathrm{~mm} /$ min. The cutting parameters can be modified in relation to the material type. This equipment enables vibrationless cutting of the hard inclusions without disturbing the clay matrix (Fig. 7). After cutting one end of the specimen, a parallel cut of the other end can be achieved by rotating the prismatic adapter by $180^{\circ}$. Small cavities in the surface and irregularities of the end surfaces were filled with own sample material, i.e. the saw dust was moistened and used as a non-hardening plaster. During cutting, the samples were protected against drying by covering with a plastic foil and wet cloth. Thanks to the polishing, no further treatment of the end surfaces was necessary. After cutting, the specimen was weighed, photographed and measured.

The specimens used in the first two triaxial compression tests had a height $H$ to diameter $D$ ratio ("slenderness ratio") of 2, which accords with standard test procedures. In the subsequent tests, a slenderness ratio of $H / D=1$ was chosen to reduce the test duration, which was anyway very long due to the extremely low hydraulic conductivity of the breccia (Sect. 4.1). A low slenderness ratio is potentially problematic, however, because of the friction between the end surfaces of the specimen and the loading plates. Without lubrication of the end surfaces, the friction will affect the results, usually leading to an overestimation of the strength. In order to reduce the friction, polished stainless steel plates and a circular latex membrane material with a thickness of $2.6 \mathrm{~mm}$, separated by a film of silicone grease, were applied on both ends of the specimen (Head 1998). In order to allow drainage of the specimen,

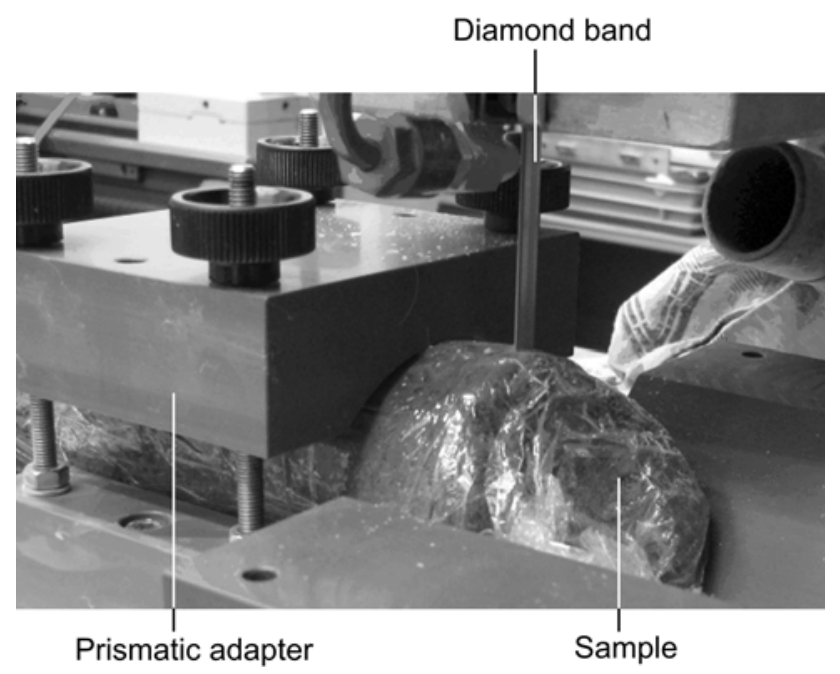

Fig. 7 Cutting device both the plates and the membranes have a small central hole. A circular filter plate closes the hole in the metal plates. In order to achieve more homogeneous drainage conditions at both ends of the specimen, radially arranged strips of filter paper were positioned there (Fig. 8). Friction at the end surfaces of the specimen also has an effect on the shape of the deformed specimen, leading either to a barrellike shape or to the development of a distinct shear plane. A homogeneous deformation of the specimen, such as the one in Fig. 9, therefore indicates that the lubrication of the end surfaces was effective.

The ratio between specimen diameter and the largest grain should be at least 10:1 (ISRM 1983), otherwise the strength and deformability results may show a considerable scatter. The scatter can be attributed to locally irregular deformations of the specimen, e.g. due to interlocking between the particles. In the present case, the largest grain of the samples was about $1 \mathrm{~cm}$ big (Fig. 5) and the specimen diameter was equal to $6.3 \mathrm{~cm}$, i.e. their ratio was equal to about $6: 1$. This relatively small ratio is suitable for triaxial testing, because no interlocking during shearing is

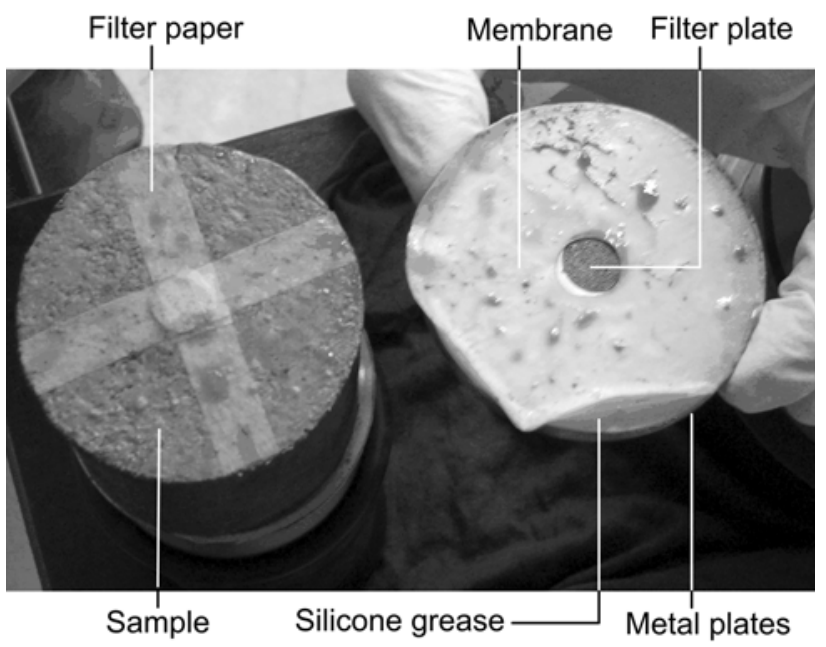

Fig. 8 Lubrication and drainage of end surfaces

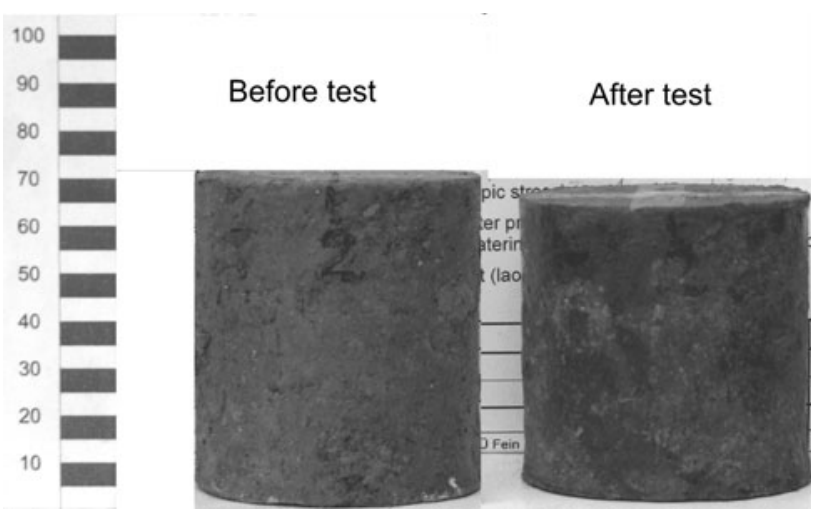

Fig. 9 Sample Z05 prior and after tests 


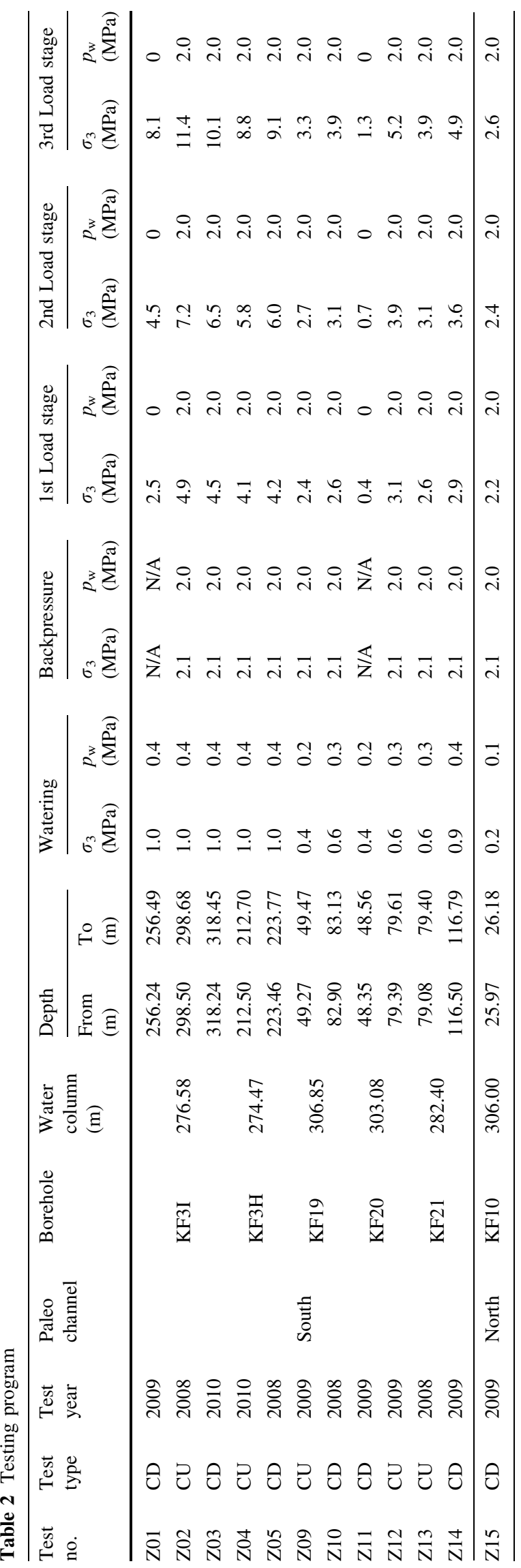

expected as the breccias consist of a chaotic mixture of blocks and stones embedded in a clay matrix (Fig. 4).

\subsection{Test Procedure in the CD and CU Tests}

\subsubsection{Watering and Backpressure}

Even with protection of the cores and optimal climatic conditions during storage, the possibility of a certain loss of pore water during storage and specimen preparation cannot be entirely excluded. In order to reconstitute the in situ condition as far as possible, the samples were brought to a saturated state. In a first step, the sample was loaded isotropically by $0.2-1 \mathrm{MPa}$ (see Table 2 , column "watering$\sigma_{3}$ "). Then a water pressure of $0.1-0.4 \mathrm{MPa}$ (see Table 2, column "watering- $p_{\mathrm{w}}$ ") was applied at the bottom boundary of the sample, while its top boundary was maintained under atmospheric pressure. As the amount of deaired water pushed into the sample is measured over time, the watering phase also allows hydraulic conductivity to be determined. The latter was carried on until stationary state could clearly be observed. Consequently, the duration of the watering stage depends on the hydraulic conductivity.

After watering, a high backpressure was applied to both ends of the specimen in order to dissolve the remaining air bubbles captured in the pores and thus increase the degree of saturation. After several days, the water valves were closed and the Skempton's $B$ value was also measured to determine the degree of saturation. The $B$ value is defined by the following equation (Skempton 1954):

$B=\frac{\Delta p_{\mathrm{w}}}{\Delta \sigma_{3}}$,

where $\Delta p_{\mathrm{w}}$ denotes the increment in the pore pressure after increasing the radial pressure by $\Delta \sigma_{3}$ under undrained conditions. For a saturated sample,

$B=\frac{1}{1+n \frac{C_{\mathrm{w}}}{C_{\mathrm{s}}}}$,

where $n, C_{\mathrm{w}}$ and $C_{\mathrm{s}}$ denote porosity, the compressibility of the water and the compressibility of the specimen skeleton, respectively. The $B$ value of a saturated specimen is practically equal to 1 if the compressibility of the sample skeleton is much higher than the compressibility of the pore water $\left(4.6 \times 10^{-4} \mathrm{MPa}^{-1}\right)$ and the pores are interconnected. Soil specimens fulfil these conditions as a soil skeleton has a compressibility of about $10^{-1}$ to $10^{-2} \mathrm{MPa}^{-1}$. The $B$ values of rock specimens may be considerably lower than 1 because the compressibility of their skeleton is as low as that of the pore water. For example, the $B$ values of saturated granite and sandstone specimens have been found to be lower than 0.5 (Lambe and Whitman 1969). 
In order to control the degree of saturation, the backpressure was applied stepwise in three stages. In each stage, first the water valves were kept closed and the isotropic load was increased by $\Delta \sigma_{3}$. As a consequence, the pore pressure increased immediately. The valves were kept closed until equilibrium was achieved. Then, the pressure at the pore water pressure device was increased to the theoretical value, i.e. for having a $B$ value of 1 , and the valves were opened. The amount of water being impelled in the specimen was observed until reaching again equilibrium. Afterwards the valves were closed and a new step of the backpressure stage was started. For all samples, the isotropic load and the pore pressure at the end of the backpressure stage were 2.1 and $2.0 \mathrm{MPa}$. After the last backpressure stage, the $B$ values for all samples were higher than 0.9. Based on the formulation proposed by Lade and Hernandez (1977), without considering the flexibilities of the testing system and membrane, $B$ values of 0.9 indicate a degree of saturation of minimum $96 \%$.

\subsubsection{Consolidation}

After the backpressure stage, the water valves were opened and the first isotropic consolidation stage was started under an effective stress, which was taken equal to the mean effective stress in situ. The latter was estimated based on the pore pressure and the depth beneath the seabed at the location of each specimen assuming different lateral confining pressures depending on the depth. For a depth of $<170 \mathrm{~m}$, a lateral pressure coefficient of 0.8 was applied, while for the deeper samples this coefficient was set equal to one. The pressures for the watering, backpressure and consolidation phases were determined based on the estimated in situ mean stress values from Table 2.

The required consolidation time $t$ was estimated by applying Terzaghi's one-dimensional consolidation theory (Terzaghi 1943), i.e. it is based upon the solution of the classic differential equation

$c_{\mathrm{v}} \frac{\partial^{2} p_{\mathrm{w}}}{\partial z^{2}}=\frac{\partial p_{\mathrm{w}}}{\partial t}$,

where $p_{\mathrm{w}}$ is the pore pressure, $t$ the time, $z$ the coordinate in a vertical direction and $c_{\mathrm{v}}$ is the coefficient of consolidation, i.e.

$c_{\mathrm{v}}=\frac{k(1-v) E}{\gamma_{\mathrm{w}}(1+v)(1-2 v)}$,

where $\gamma_{\mathrm{w}}, v, E$ and $k$ denote the unit weight of water, the Poisson's ratio, the Young's modulus and the hydraulic conductivity of the ground, respectively.

In the present case, consolidation phase usually took 4-6 days. The theoretical degree of consolidation for this period amounts to more than $99 \%$ even if an extremely low hydraulic conductivity of $k=10^{-13} \mathrm{~m} / \mathrm{s}$ is taken into account (other parameters: slenderness ratio $H / D=1$, $D=63 \mathrm{~mm}, E=300 \mathrm{MPa}, v=0.3$ and $\gamma_{\mathrm{w}}=9.8 \mathrm{kN} /$ $\left.\mathrm{m}^{3}\right)$.

\subsubsection{Deviatoric Loading}

Two types of triaxial tests were run: so-called consolidated drained (CD) and consolidated undrained (CU) tests. In the first case, the pore pressure is kept constant during the deviatoric loading (which means that drainage of the pore water may take place). In the second case, the valves of the water pipes at both ends of the specimen are closed (which means that the volume of the specimen remains nearly constant if it is saturated) and the changes in pore pressure are measured. In both cases, the deviatoric stage is performed under controlled deformation conditions, i.e. the specimen is subjected to a constant axial deformation rate. During the deviatoric loading of a CU test, the volume of the specimen can change due to the compressibility of its constituents. However, this volume change can be neglected because the strength of the breccias is very low.

Due to the low hydraulic conductivity of the clay matrix of the breccia, even a relatively low loading rate may cause a non-uniform excess pore pressure inside the specimen. As a consequence, the effective stress field in the specimen becomes non-uniform too and the evaluation of the strength becomes unreliable. A homogeneous stress distribution can be achieved only by limiting the loading rate to an adequate value. According to Bishop and Henkel (1957), the error in the measured strength is negligible, if the dissipation degree of the excess pore pressure amounts to a minimum of $95 \%$. The time $t_{\mathrm{f}}$ needed to reach $95 \%$ dissipation at failure for CD-tests can be estimated as follows:

$t_{\mathrm{f}}=\frac{H^{2}}{0.2 \eta c_{\mathrm{v}}}$,

where $\eta$ is a factor that depends on the drainage conditions and is equal to 3 in the present case (drainage at both specimen ends). According to this equation, the required time $t_{\mathrm{f}}$ amounts to about $9.2 \mathrm{~h}$ (for $E=300 \mathrm{MPa}$, $\left.k=5 \times 10^{-12} \mathrm{~m} / \mathrm{s}, \gamma_{\mathrm{w}}=9.8 \mathrm{kN} / \mathrm{m}^{3}, H=64 \mathrm{~mm}\right)$. For an assumed axial strain $\varepsilon_{1}$ of $4 \%$ at failure, the highest allowable deformation rate amounts to $0.27 \mathrm{~mm} / \mathrm{h}$. We checked the validity of Eq. (5) by comparison with the solution of the consolidation equation (Eq. 3). Under a deformation rate of $0.27 \mathrm{~mm} / \mathrm{h}$, the excess pore pressure in the middle of the sample amounts to only $3 \%$ of the total deviatoric stress when the axial strain $\varepsilon_{1}$ reaches $4 \%$. The deformation rate is thus sufficiently slow to ensure a practically homogeneous stress distribution. In CU tests, the shear rate can be 16 times faster than in CD tests (Head 
1998). For the present investigations, the chosen axial deformation rates were $0.05-0.1 \mathrm{~mm} / \mathrm{h}$ for the CD-tests and $0.1-0.2 \mathrm{~mm} / \mathrm{h}$ for the CU-tests. The axial deformation rates were applied (while keeping the radial pressure constant) until the shear strength of the specimen was reached.

In order to get more information on the strength of the material from each specimen, the multi-stage test technique suggested by ISRM (1983) was applied both for the CD and the CU triaxial tests. This technique is particularly suitable for the present material as it exhibits a ductile behaviour. Therefore, after reaching failure as indicated above, each sample was unloaded axially to the hydrostatic stress. Then, the hydrostatic stress was increased and kept constant until consolidation was nearly complete. Afterwards the next deviatoric loading stage was started. This procedure was repeated for a third loading stage. Table 2 shows the boundary conditions for the consolidation and deviatoric load stages. The CD-tests also included an unloading-reloading cycle for each stage to determine the elastic moduli.

The effective stresses $\sigma^{\prime}$ have been calculated by applying the conventional concept of effective stresses for saturated soils, i.e. $\sigma^{\prime}=\sigma-p_{\mathrm{w}}$, where $\sigma$ is the total stress. Following Vogelhuber (2007), the actual cross section area of the deformed specimen was considered for the computation of total stress. The deformed cross sectional area was estimated assuming a homogeneous volumetric deformation. The latter can be calculated from the axial deformation of the specimen and the displacement of the piston of the pressure amplifier (i.e. from the oil volume that is pushed out from the triaxial cell). Instant oil volume changes due to increases in radial pressure prior to a consolidation phase, i.e. between the loading stages, are primarily attributed to the elastic deformation of the test equipment and were disregarded in the cross-sectional area calculations.

It should be noted, however, that in the present case the corrected axial stress is only slightly lower than the uncorrected value. The difference is only $2 \%$ when $\varepsilon_{1}$ is below $5 \%$, which is rather negligible. The deviation is still $<5 \%$ when $\varepsilon_{1}$ is $10 \%$. This is due to the plastic volumetric behaviour of the breccias, which is rather contractant (see Sect. 4.2). In the case of dilatant behaviour, the circumference of the sample increases considerably during plastic yielding and the error increases (Vogelhuber 2007). In this case, however, the type of analysis (large vs. small strain) should be taken into account when evaluating the results.

\subsection{Corrections of Test Results}

During execution of the test program, two problems became evident, which were not observed in previous triaxial tests on weak rock samples in our laboratory
(Vogelhuber 2007; Anagnostou et al. 2008): (1) static friction between the loading piston and the cell; (2) temperature variation effects. As explained below, these problems were associated with the very low strength, stiffness and hydraulic conductivity values of the breccia and they must be taken into account in the evaluation of the test results.

\subsubsection{Static Friction Between Piston and Cell}

The original stress-strain curves of a CD-test (Fig. 10a) show that a small axial movement of the piston of the triaxial cell causes a large increase in the axial force at the start of loading (and a large decrease in the axial force at the start of unloading). These observations, which suggest an unrealistically high stiffness of the breccias, are due to the static friction force that must be overcome to move the piston of the cell (and also after reversing the loading direction). The piston has a diameter of $140 \mathrm{~mm}\left(D_{\mathrm{p}}\right.$ in Fig. 6) and contains two carbon bands as guidance with O-rings for sealing (Fig. 11). The sealing system (carbon bands and O-rings) is the source of friction.
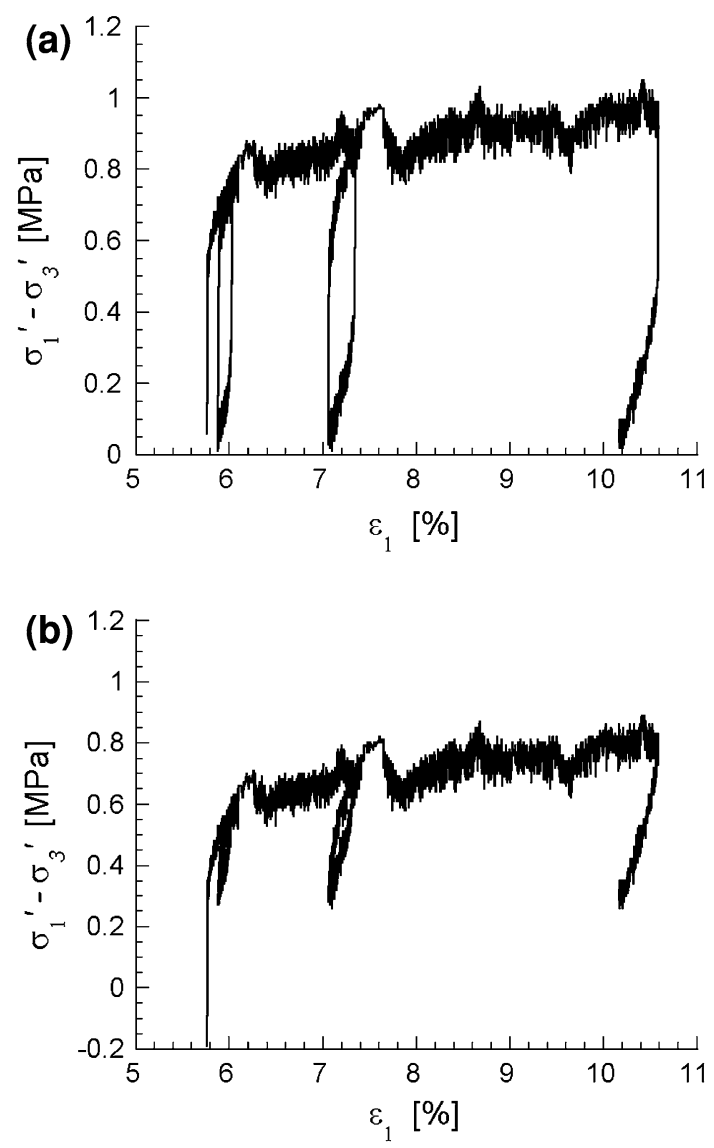

Fig. 10 Test results of the stress-strain curve of sample Z15 (1st load stage): a original stress-strain curve; b corrected stress-strain curve taking account of the friction 


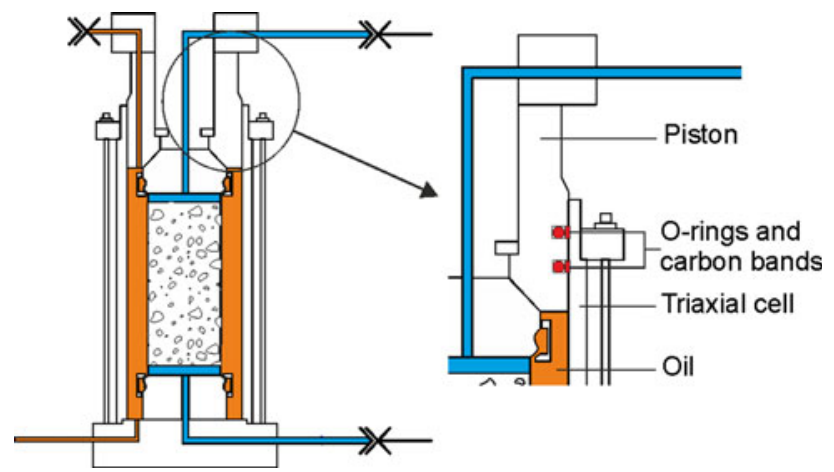

Fig. 11 Sketch of the triaxial cell and location of O-rings

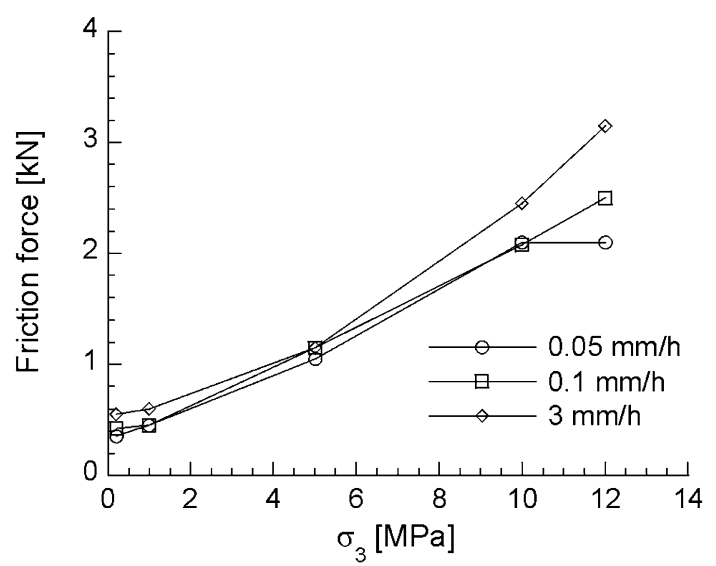

Fig. 12 Relationship between the friction force and the radial pressure at different axial loading rates

In order to quantify the magnitude of the friction force, a series of calibration tests were carried out without putting a specimen in the cell. The triaxial cell was filled completely with oil. The water connectors were tightened to prevent the oil coming into or out of the cell. Then, a constant displacement rate was applied to the loading piston while maintaining a constant oil pressure (which would be identical to the radial pressure in the case of a normal test). The friction force corresponds to the force increase necessary for allowing the piston to slide in the cell. Several loading and unloading cycles were performed under different radial pressures and displacement rates. Due to the static friction, a reversal in the direction of displacement leads to a force change twice as large as the friction force. According to Fig. 12, the friction force increases almost linearly with the oil pressure, while the loading rate has only a minor influence. The effect of oil pressure on the friction force becomes evident when considering the sealing system (Fig. 11): the oil pushes the carbon bands and the O-rings towards the steel, thus increasing the contact stress and frictional resistance between the steel and the carbon band.

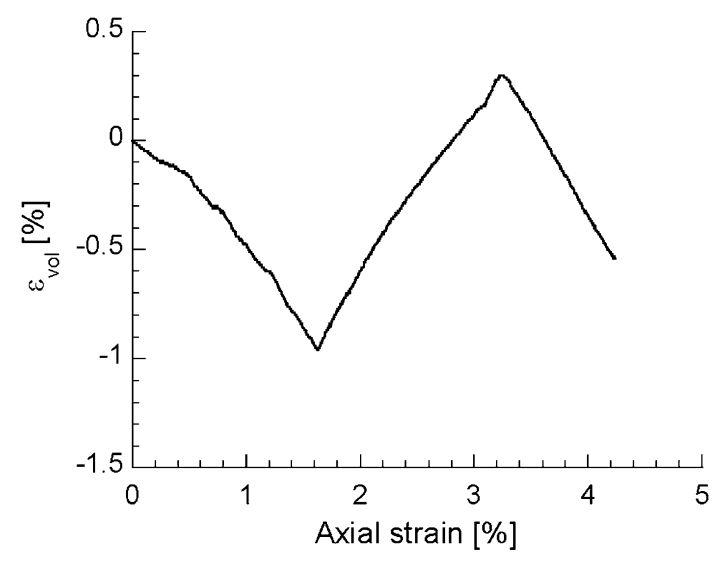

Fig. 13 Apparent volumetric strain of a CU-test during shearing (sample Z12, 1st loading stage)

Figure 10b shows the corrected stress-strain curves after taking into account the frictional component of the axial force. The unloading/reloading modulus was decreased from 516 to $230 \mathrm{MPa}$ and from 295 to $137 \mathrm{MPa}$ for the two cycles. Due to the friction, the unloading-reloading process was not completed, i.e. the axial stress did not decrease to the same value as the radial stress. According to experiences with kakiritic rocks, the elastic hysteresis is significant during unloading and reloading. Therefore, it is difficult to evaluate the elastic modulus accurately considering the incomplete unloading-reloading cycle. The influence of the friction correction on the strength parameters will be discussed in more detail in Sect. 4.1.

\subsubsection{Influence of Temperature Variation on the Volumetric Strain}

Saturated specimens under the conditions of CU triaxial tests should not experience any volume change. However, the test results show an approximately cyclical fluctuation in the volumetric strain $\varepsilon_{\mathrm{vol}}$ with maximum changes of about $1.5 \%$ (Fig. 13). Due to the low hydraulic conductivity of breccias, the duration of each test stage is 1-2 days. For comparison, it should be noted that typical triaxial CD tests on weak saturated rock take only 3-4 h. Since our rock mechanics laboratory is air-conditioned but does not provide precise temperature regulation, the temperature may vary by $2-3{ }^{\circ} \mathrm{C}$ between day and night and by $3-4{ }^{\circ} \mathrm{C}$ over the weekends. The possibility was therefore checked that these apparently cyclical volumetric strains could be due to measuring errors associated with the cyclical temperature changes.

In the present case, the volumetric strain is not measured directly, but it is calculated from the change in the volume of oil in the test system, i.e. in the triaxial cell, in the hoses and in the pressure amplifier (marked black in Figs. 6 

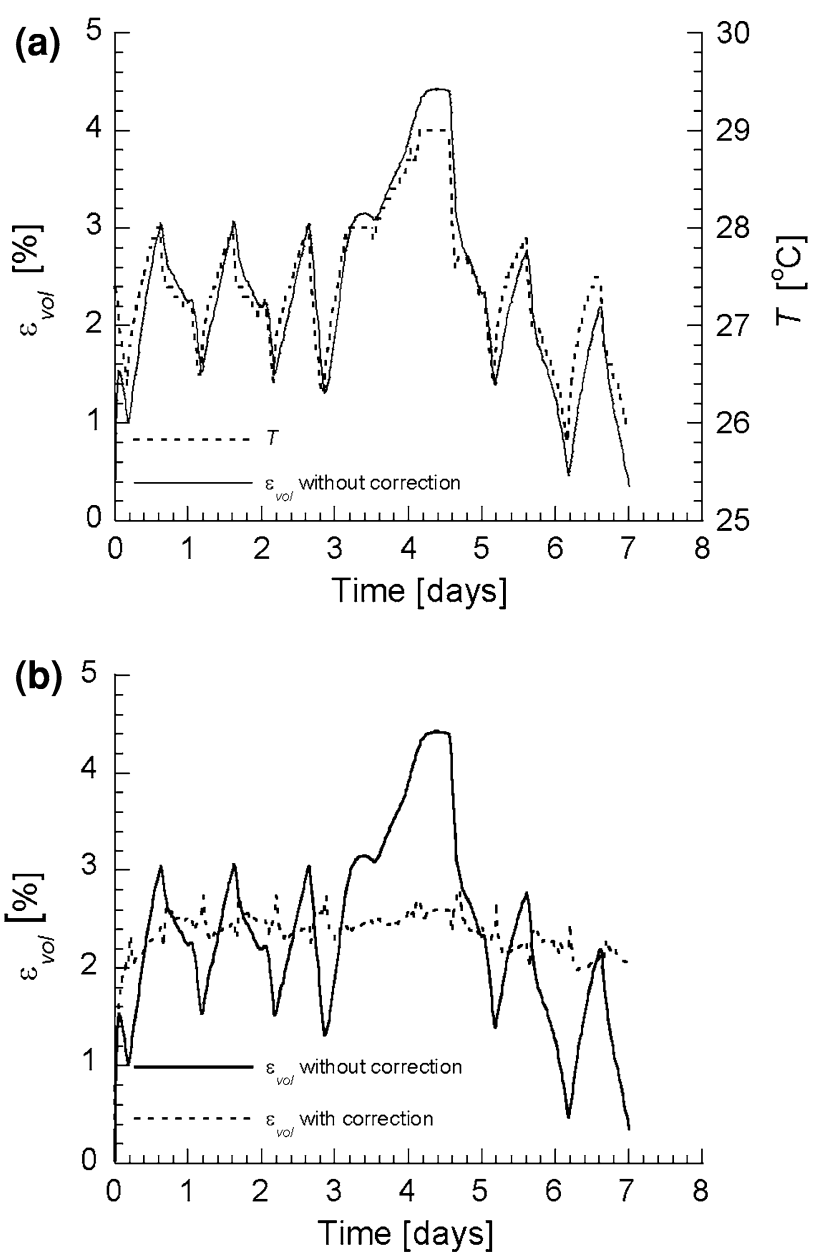

Fig. 14 a Temperature and apparent volumetric strain over time. b Corrected and apparent volumetric strain over time

and 11). The oil volume change is measured via the displacement of the oil pressure amplifier cylinder. A temperature-induced change in the oil volume would cause a displacement of the cylinder ( $\Delta h_{\mathrm{o}}$ in Fig. 6) even if the volume of the breccia sample remains constant.

In order to quantify the effect of the oil temperature $T$ on the displacement of the oil pressure amplifier cylinder, a test was carried out in which the oil pressure was kept constant and the location of the axial loading piston was fixed $\left(\Delta h_{\mathrm{p}}=0\right.$, see Fig. 6). In this way all factors causing an oil volume change were eliminated with the exception of oil temperature changes in the triaxial cell, which were monitored by a type PT100 thermistor. The measurements show that both $\varepsilon_{\mathrm{vol}}$ and $T$ fluctuate cyclically and correlate very well together (Fig. 14a).

In conclusion, temperature effects may be relevant in the case of lengthy triaxial tests, which are needed, if the samples have an extremely low permeability. The thermal expansion of the oil introduces errors into the measurement of the volumetric strain of the specimen and should be taken into account in the calculation of the volumetric strain $\varepsilon_{\mathrm{vol}}$ (see Appendix for computational details). Figure $14 \mathrm{~b}$ shows the apparent volumetric strain $\varepsilon_{\mathrm{vol}}^{\mathrm{o}}$ over time as well as the volumetric strain after the correction for temperature effects $\left(\varepsilon_{\mathrm{vol}}^{\mathrm{o}, \mathrm{corr}}\right)$. It is clear that compensating for the temperature effect practically eliminates the fluctuation (the fluctuation in the corrected volumetric strain is less than $\pm 0.2 \%$ ).

For the observed temperature difference between day and night (up to $2-3{ }^{\circ} \mathrm{C}$ ), the error in the volumetric strain might be as high as $2-3 \%$ (Fig. 14a), which is of the same order of magnitude as the expected volumetric strain during shearing. Unfortunately, the effects of temperature became apparent only after a lengthy period of testing. Therefore, the temperature was not measured in the tests and a reliable correction of the oil volume-based measurements is no longer possible.

Alternatively, in the $\mathrm{CD}$ tests, the volumetric strain can also be evaluated via the volume of the water that is expelled from the sample during shearing and consolidation. This method was applied by Chiu et al. (1983) and its accuracy was found to be satisfactory, provided that one applies a back pressure (to ensure that the samples remain saturated). Except for the partially saturated samples Z01 and $\mathrm{Z} 11$, which were tested without back pressure, all other samples used for CD-tests fulfil these conditions. Estimating volumetric strain via the water volume is advantageous because the error caused by temperature fluctuation is considerably smaller than with the oil volume: (1) the quantity of water in the testing system $V_{\mathrm{w}}$ (marked gray in Fig. 6) is smaller than the quantity of oil (marked black in Fig. 6) and (2) water has a lower thermal expansion coefficient than oil. A temperature change of $2-3{ }^{\circ} \mathrm{C}$ causes an apparent volumetric strain in the specimen of only $0.08-0.12 \%$, which is 30 times smaller than in the case of oil (see Appendix).

\section{Results and Discussion}

\subsection{Strength Parameters and Hydraulic Conductivities}

The strength of the specimens is evaluated in terms of effective stresses with reference to the Mohr-Coulomb failure criterion. The stresses are calculated assuming a homogeneous stress field in the specimen and taking account of changes to the cross section (Sect. 3.4.3). The strength is evaluated at the maximum effective deviatoric stress during each deviatoric loading stage. The shear parameters are calculated with a linear regression taking account of the strength at three different radial pressures. As explained in Sect. 3.5.1, the measured axial force must be corrected in light of the friction between piston and cell 
Table 3 Strength parameters, hydraulic conductivity and loading rates of tested samples

\begin{tabular}{|c|c|c|c|c|c|c|c|c|c|}
\hline \multirow[t]{2}{*}{ Test no. } & \multirow[t]{2}{*}{ Test type } & \multirow[t]{2}{*}{ Zone } & \multicolumn{2}{|c|}{ Original strength } & \multicolumn{2}{|c|}{ Corrected strength } & \multirow[t]{2}{*}{$k(\mathrm{~m} / \mathrm{s})$} & \multirow{2}{*}{$\begin{array}{l}\text { Loading rate } \\
(\mathrm{mm} / \mathrm{h})\end{array}$} & \multirow{2}{*}{$\begin{array}{l}\text { Test duration } \\
\text { (days) }\end{array}$} \\
\hline & & & $c^{\prime}(\mathrm{MPa})$ & $\phi^{\prime}\left({ }^{\circ}\right)$ & $c^{\prime}(\mathrm{MPa})$ & $\phi^{\prime}\left({ }^{\circ}\right)$ & & & \\
\hline $\mathrm{Z} 01$ & $\mathrm{CD}$ & & 0.407 & 15.2 & 0.376 & 14.3 & $4.67 \mathrm{E}-12$ & 0.05 & 35 \\
\hline $\mathrm{Z} 02$ & $\mathrm{CU}$ & & 0.717 & 8.1 & 0.611 & 7.1 & $9.92 \mathrm{E}-12$ & 0.15 & $76(H / D=2)$ \\
\hline $\mathrm{Z} 03$ & $\mathrm{CD}$ & Lower & 1.211 & 12.4 & 1.306 & 9.4 & $1.62 \mathrm{E}-12$ & 0.10 & 97 \\
\hline Z04 & $\mathrm{CU}$ & & 0.464 & 15.0 & 0.367 & 13.7 & $9.36 \mathrm{E}-13$ & 0.10 & 93 \\
\hline $\mathrm{Z} 05$ & $\mathrm{CD}$ & & 0.392 & 10.2 & 0.327 & 9.0 & $3.86 \mathrm{E}-13$ & 0.05 & 54 \\
\hline$\overline{Z 09}$ & $\mathrm{CU}$ & & 0.445 & 26.9 & 0.375 & 26.0 & $9.40 \mathrm{E}-12$ & 0.10 & 30 \\
\hline $\mathrm{Z} 10$ & $\mathrm{CD}$ & & 0.162 & 21.0 & 0.076 & 20.4 & $1.13 \mathrm{E}-11$ & 0.10 & $49(H / D=2)$ \\
\hline $\mathrm{Z} 11$ & $\mathrm{CD}$ & & 0.260 & 26.9 & 0.233 & 26.4 & $2.09 \mathrm{E}-11$ & 0.05 & 22 \\
\hline $\mathrm{Z} 12$ & $\mathrm{CU}$ & Upper & 0.184 & 25.4 & 0.120 & 24.5 & $1.52 \mathrm{E}-11$ & 0.10 & 36 \\
\hline $\mathrm{Z13}$ & $\mathrm{CU}$ & & 0.178 & 22.2 & 0.107 & 21.1 & $5.76 \mathrm{E}-12$ & 0.20 & 28 \\
\hline Z14 & $\mathrm{CD}$ & & 0.370 & 19.8 & 0.263 & 20.1 & $2.09 \mathrm{E}-12$ & 0.05 & 49 \\
\hline $\mathrm{Z} 15$ & $\mathrm{CD}$ & & 0.177 & 22.6 & 0.108 & 22.2 & $6.69 \mathrm{E}-12$ & 0.05 & 39 \\
\hline
\end{tabular}

wall. Table 3 shows both the original and the corrected strength parameters. The friction correction leads to lower strength parameters $c^{\prime}$ and $\phi^{\prime}$. In test Z10, for example, $c^{\prime}$ and $\phi^{\prime}$ decreased by $0.086 \mathrm{MPa}$ and $0.6^{\circ}$, respectively. In the following discussion, only the corrected values will be used. No significant deviation of strength parameters was observed between samples under different slenderness ratios (see Table 3 ). It suggested that the reduction of the slenderness ratio does not affect the strength properties if the lubrication of the end surfaces was considered (see Sect. 3.3).

Figure 15 provides an overview of the strength envelopes in the $\left(p^{\prime}, q^{\prime}\right)$-space, while Fig. 16 shows the strength parameters and hydraulic conductivity over depth. According to the experimental results, the samples from two groups: the samples of the first group stem from the upper zone of the paleo-channel (depth $<120 \mathrm{~m}$, solid lines in Fig. 15); the other samples stem from the lower zone (depth between 200 and 320 m, dashed lines in Fig. 15). In

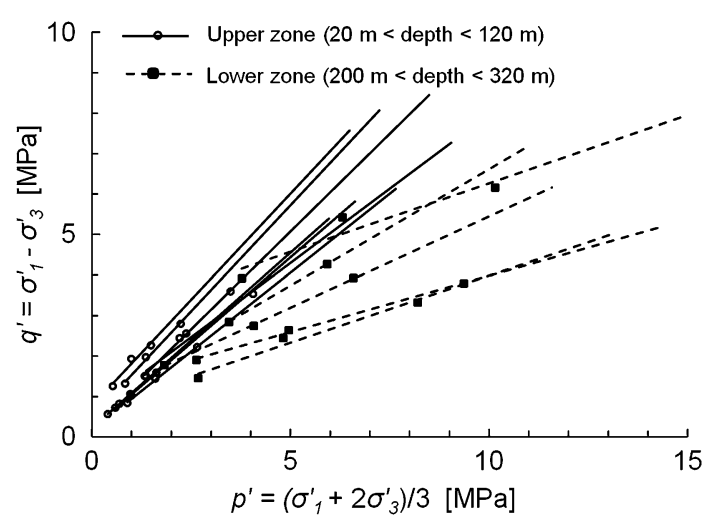

Fig. 15 Strength envelopes of tested samples the upper zone (samples Z09, Z10, Z11, Z12, Z13, Z14 and Z15; marked by white circles in Fig. 16), the friction angle $\phi^{\prime}$ varies between $20.1^{\circ}$ and $26.4^{\circ}$, the cohesion $c^{\prime}$ varies between 0.076 and $0.375 \mathrm{MPa}$ and the hydraulic conductivities $k$ varies between $2.1 \times 10^{-11}$ and $2.1 \times 10^{-12} \mathrm{~m} / \mathrm{s}$. In the lower zone (samples Z01, Z02, Z03, Z04 and Z05; marked by black rectangles in Fig. 16), the parameters $\phi^{\prime}, c^{\prime}$ and $k$ amount to $7.1^{\circ}-14.3^{\circ}, 0.327-1.306 \mathrm{MPa}$ and $9.9 \times 10^{-12}$ to $3.8 \times 10^{-13} \mathrm{~m} / \mathrm{s}$, respectively. A tendency can be seen for greater cohesion and smaller friction angles with depth. These results indicate that the initial stress influences considerably the properties of the breccias. Note that the actual vertical alignment of the tunnel ( $B 1$ in Fig. 2) crosses the breccias at a depth of about $200 \mathrm{~m}$, i.e. at the top of the lower zone.

\subsection{Volumetric Behaviour}

As explained in Sect. 3.5.2, temperature changes influence the volume of the oil and thus the apparent volumetric strain of the specimen considerably. Measuring volumetric strain via the water volume change is far more accurate. Figure $17 \mathrm{a}$ shows the time-development of the volumetric strain $\varepsilon_{\mathrm{vol}}$ during the consolidation stage as determined via oil volume and water volume. The volumetric strain determined via water volume increases smoothly with time, while the oil volume-based volumetric strain displays greater fluctuation. Figure $17 \mathrm{~b}$ shows the volumetric strains $\varepsilon_{\mathrm{vol}}$ according to the two methods of determination for the deviatoric stage of the test. The volumetric strain $\varepsilon_{\mathrm{vol}}^{\mathrm{o}}$ determined via oil volume indicates contractant behaviour, but is superposed by the typical, thermally induced cyclical error. The volumetric strain $\varepsilon_{\mathrm{vol}}^{\mathrm{W}}$ determined via water volume increases smoothly with axial 

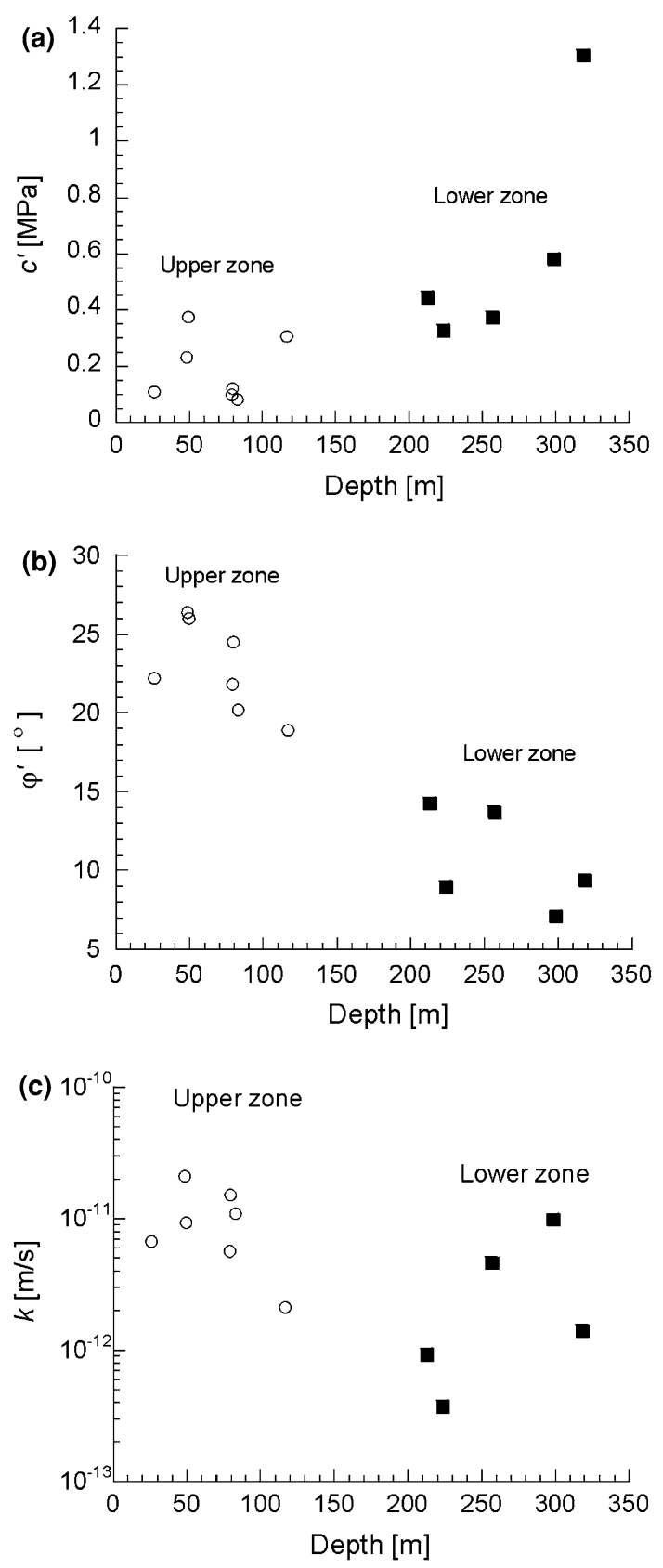

Fig. 16 a Cohesion, b friction angle and $\mathbf{c}$ hydraulic conductivity over depth

strain and shows a less contractant behaviour during the entire shearing stage. The determination of volumetric strain via oil volume generally leads to higher values than a determination based on water volume. This may be due to occasionally oil leakages, which occur at very low rates but become relevant in the present case due to the very long test durations. It has to be mentioned that no significant deviation of volumetric behaviour was observed between samples under different slenderness ratios.

Figure 18 shows the development of the deviatoric stress $q^{\prime}$ and of the excess pore pressure $p_{\mathrm{w}}$ over axial strain
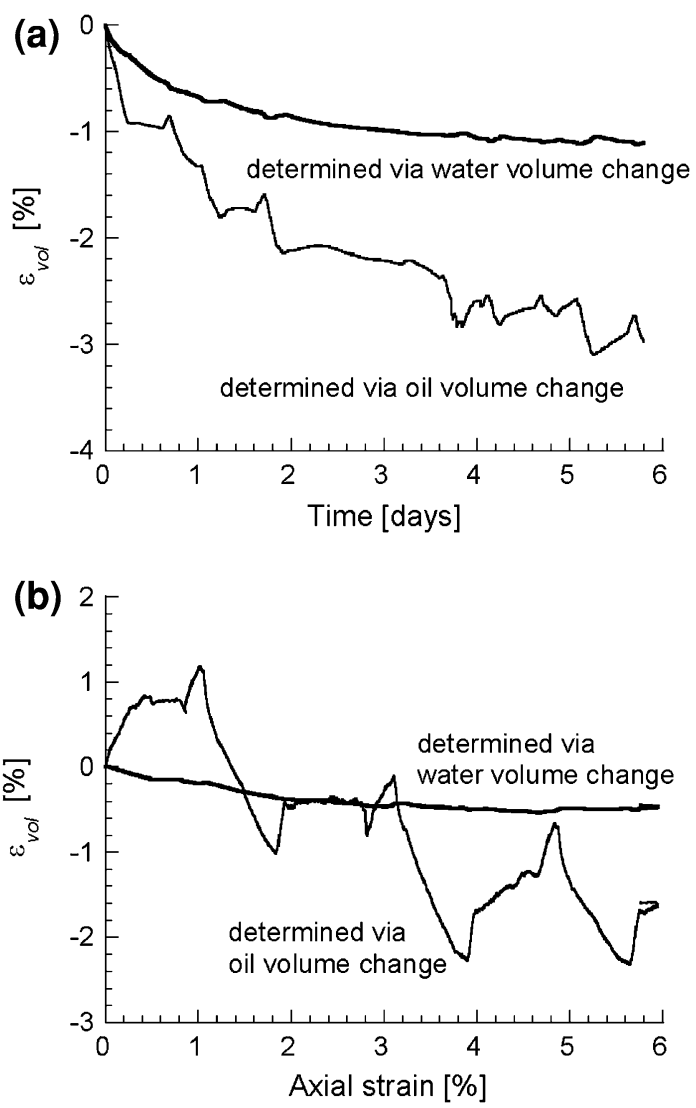

Fig. 17 Volumetric strain over time during, a consolidation (Z14, 1st consolidation stage) or, b deviatoric shearing (Z15, 1st loading stage, CD)

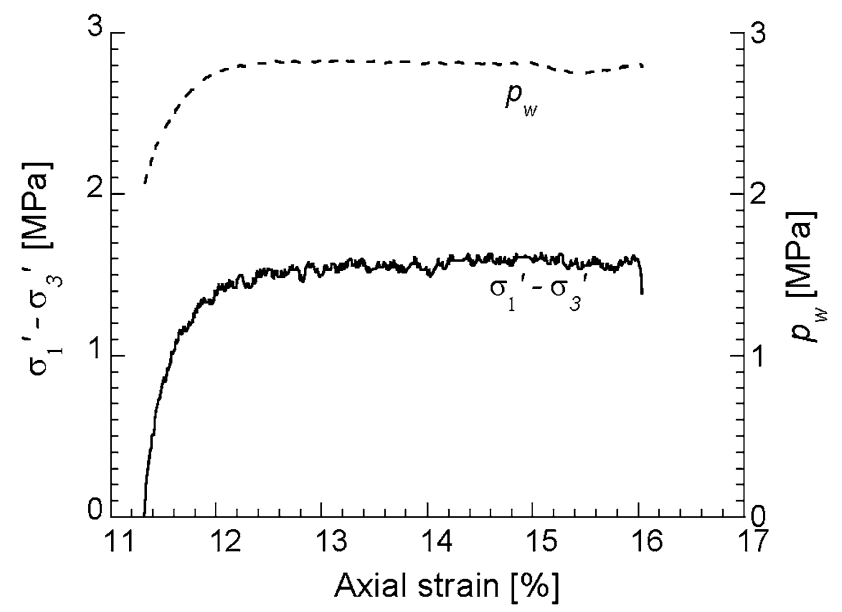

Fig. 18 Typical stress-strain curve in CU tests (Z13, 3rd loading stage)

for a CU-test (Z13, 3rd load stage). The pore pressure increases continuously with deviatoric stress before failure. After failure, both pore pressure and deviatoric stress remain constant. The constant pore pressure during yielding indicates that the sample has reached the so-called critical state (Schofield and Wroth 1968). 


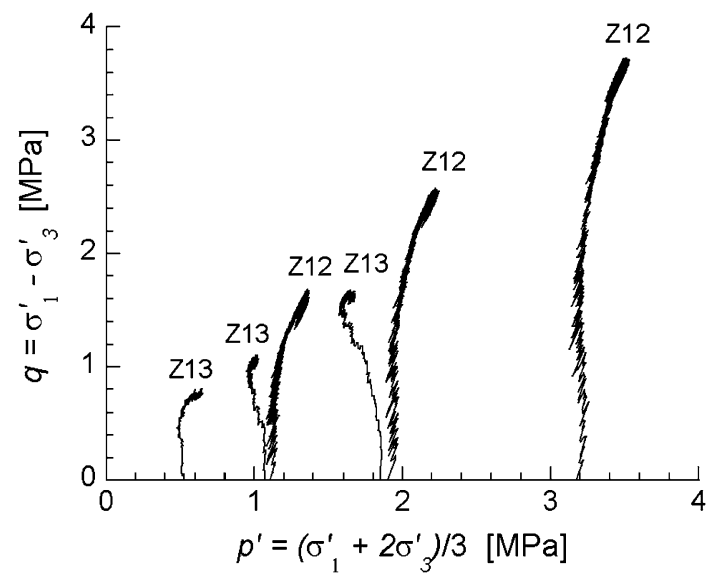

Fig. 19 Stress paths for samples $\mathrm{Z} 12$ and $\mathrm{Z13}$

Figure 19 shows the stress paths of samples Z12 and $\mathrm{Z} 13$ in the $p^{\prime}-q^{\prime}$-space. In the case of sample Z13, the effective isotropic pressure $p^{\prime}$ decreases before failure, i.e. the pore pressure increases, which mean that the behaviour before failure is contractant. This observation was made for most of the CU samples. Sample Z12 is the only exception, exhibiting a slightly dilatant behaviour before failure as indicated by the increment of effective isotropic pressure $p^{\prime}$. It is interesting to note, however, that $p^{\prime}$ ceases to increase after failure. Samples Z12 and Z13 exhibit a different volumetric behaviour before failure, but both reach a critical state and have about the same strength parameters.

According to the results of the $\mathrm{CD}$ and $\mathrm{CU}$ triaxial tests and in line with critical state theory (Schofield and Wroth 1968), the breccias behave like a normally consolidated or slightly over-consolidated soil. This is plausible because there is no geological evidence that the breccias from Gibraltar were exposed to considerably higher stresses in the past, e.g. resulting from tectonic action or glacial deposition (cf. Luján et al. 2011). The evaluation of Skempton's pore pressure parameter $A$ for the CU tests provides additional evidence that the breccias are normally or slightly over-consolidated. The $A$ parameter is defined as:

$A=\frac{\Delta p_{\mathrm{w}}}{\Delta \sigma_{1}}$,

where $\Delta p_{\mathrm{w}}$ and $\Delta \sigma_{1}$ denote the increment in pore pressure and axial stress during shearing, respectively. In the present CU tests, $A_{\mathrm{f}}$ (i.e. $A$ at failure) varied between 0.15 and 0.45 . The typical $A_{\mathrm{f}}$ values are $0.5-1.0$ for normally consolidated soils, $0-0.5$ for slightly over-consolidated soils and negative for over-consolidated soils (Vallejo and Ferrer 2009).

On the other hand, and in contrast to other marine soils, there is no reason to believe that the breccias are underconsolidated, i.e. that the pore pressure in situ is higher than the one corresponding to the depth beneath sea level. The genesis and estimated age of the breccias, which is more than 5 million years (Sect. 2.2), indicates that the breccias must have completed their consolidation process.

\subsection{Comparison with Kakirites}

Kakirites are broken or intensively sheared rocks, which have lost a large part of their original strength (Schneider 1997). Kakiritic gneisses, slates, and phyllites belong to the potentially heavily squeezing rocks. It is worthwhile comparing the mechanical behaviour of breccias with the behaviour of kakirites because the latter are well known from alpine tunnelling and there are some interesting similarities and differences.

For this purpose, we consider here the kakirites of the Tavetsch intermediate massif and the Clavaniev zone of the Gotthard Base Tunnel (Vogelhuber and Kovári 1998, 2000; Anagnostou et al. 2008). During the design phase of this tunnel, more than 60 triaxial CD- and CU-tests were performed on samples from borehole S.B. 3.2 (a 1,716-m-long inclined exploratory borehole, cf. Vogelhuber et al. 2004a, b; Vogelhuber 2007). Later, during construction of the Sedrun section of the base tunnel, 46 triaxial CD-tests were performed on samples from horizontal exploratory boreholes and their results assisted decision making in the selection of a typical excavation and support cross section (Anagnostou et al. 2008). The samples of these two campaigns will be referred to hereafter as "SB3.2 samples" and "Sedrun samples", respectively.

The SB3.2 samples were taken from depths of between $120 \mathrm{~m}$ and more than $1,000 \mathrm{~m}$, while the depth of cover of the Sedrun samples was about $1,000 \mathrm{~m}$. Most of the kakiritic samples were thus exposed to a higher overburden than the breccias of Gibraltar. The geological history and boundary conditions of the kakirites (i.e. the tectonic forces acting upon them during crustal movements and their confinement between competent rock formations) are largely unknown. This makes an estimation of the present in situ stresses (as well as of the highest in situ stresses applied in the past) much more difficult than for the breccias, for which there are no indications of past tectonic or glacial loading. The different in situ stresses and genesis may also explain the porosity differences. The kakirites are the product of tectonic shearing action, while the main processes for the breccias were landslide, sedimentation and consolidation. The porosity $n$ of $30 \%$ and the water content $w$ of $15 \%$ for the breccias are much higher than for the kakirites from Gotthard Base Tunnel $(n=10-20 \%$, $w=2-10 \%$ ) (Vogelhuber and Kovári 1998, 2000; Anagnostou et al. 2008). Although the breccias have a higher porosity, their hydraulic conductivity is considerably lower than the conductivity of the kakirites (by 2 orders of magnitude, see Table 4). The cause is probably the high clay content of the breccias. 
Table 4 Comparison of the mechanical properties of the Gibraltar breccias with those of the kakirites from Gotthard Base Tunnel (samples from exploration borehole SB3.2 and from probe drilling in Sedrun)

\begin{tabular}{llll}
\hline & Gibraltar & SB3.2 & Sedrun \\
\hline $\begin{array}{l}\text { Number of tests } \\
\quad(\mathrm{CD} / \mathrm{CU})\end{array}$ & $7 / 5$ & $59 / 8$ & $46 / 0$ \\
$c^{\prime}(\mathrm{MPa})$ & $0.1-1.3$ & $0.2-0.6$ & $0.2-0.6$ \\
$\phi^{\prime}\left({ }^{\circ}\right)$ & $7-26$ & $25-30$ & $25-30$ \\
Porosity $(\%)$ & 30 & $10-20$ & $10-20$ \\
$\quad$ Water content $(\%)$ & 15 & $2-8$ & $5-10$ \\
$\begin{array}{l}\text { Overburden }(\mathrm{m}) \\
\text { Water table (m) }\end{array}$ & $50-300$ & 1,000 & $750-900$ \\
$\begin{array}{l}\text { Effective radial stress } \\
\quad(\mathrm{MPa})\end{array}$ & $0.2-9$ & $1-9$ & $2-9$ \\
$\begin{array}{l}\text { Hydraulic conductivity } \\
\quad(\mathrm{m} / \mathrm{s})\end{array}$ & $10^{-11}$ to & $10^{-9}$ to & $10^{-8}$ to \\
$\begin{array}{l}\text { Shear ratio (mm/h) } \\
\text { Test duration (days) }\end{array}$ & $0.05-0.2$ & $0.3-3$ & 3 \\
\hline
\end{tabular}

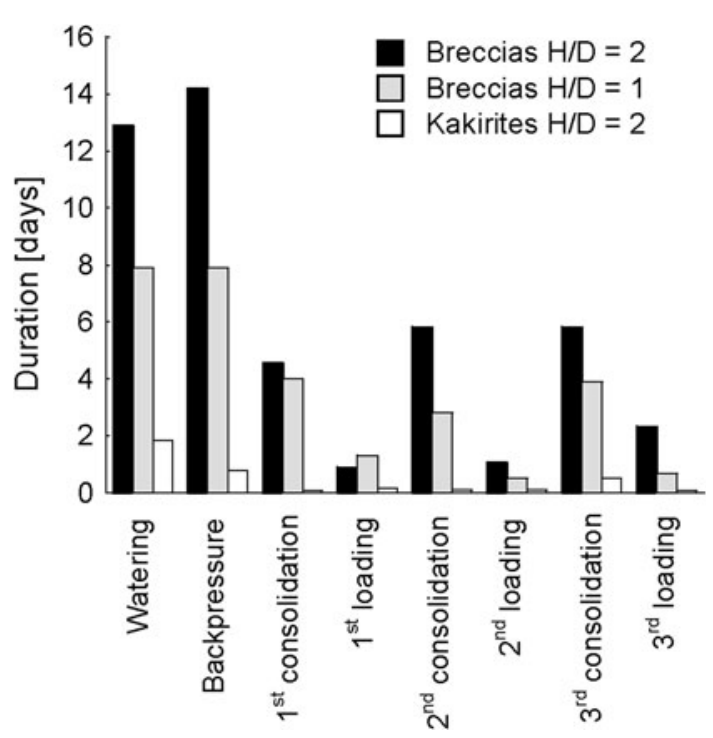

Fig. 20 Duration of test phases

Due to the big difference in hydraulic conductivity between the breccias and kakirites, the test duration is much longer for the former than for the latter, despite the fact that the breccia samples were smaller (with a lower slenderness-ratio) and their drainage paths shorter. Figure 20 shows the typical duration of different testing stages for breccia and kakiritic samples. For the breccias, data from the two samples are presented showing different slenderness ratios $H / D$ but similar hydraulic conductivity $\left(10^{-11} \mathrm{~m} / \mathrm{s}\right)$. The reduction in the slenderness ratio is very effective with respect to test duration (a reduction of almost $50 \%$ ). The hydraulic conductivity of the kakirites, which is about ten times higher than that of the breccias, explains their considerably shorter test duration.
Figure 21 shows typical results of tests on kakirite and breccia samples under approximately similar effective radial pressures $\left(\sigma_{3}^{\prime}=1.5-2 \mathrm{MPa}\right)$. The breccias have lower shear strength. Their friction angle $\phi^{\prime}$ amounts to $7^{\circ}-26^{\circ}$ (Table 4 ), while the kakirites have a friction angle of $25^{\circ}-30^{\circ}$. The cohesion $c^{\prime}$ of the breccias varies over a much wider range $(0.1-1.3 \mathrm{MPa})$ than the cohesion of the kakiritic samples from Sedrun and from SB 3.2 $(0.2-0.6 \mathrm{MPa})$. In addition, the strength parameters of the breccias depend on the depth of the samples (Fig. 16), but those of the kakirites fall within a relatively narrow range despite the fact that the specimens were widely distributed in space.

The most interesting difference between the breccias and the kakirites (and perhaps the most important from a tunnelling perspective) concerns the volumetric strain developing before and after failure. The kakirites (in contrast to the breccias) exhibit dilatant behaviour at failure in triaxial CD tests (Fig. 21c). In CU tests, the dilatant behaviour leads to a continuously decreasing pore pressure after failure. The negative excess pore pressure increases the effective stresses and thus also the strength (so-called dilatancy hardening, Rice 1975). Most breccia samples exhibited contractant plastic flow before failure (Fig. 19). In all CU tests with breccia, the pore pressure remained constant after reaching failure, which means that the behaviour is neither dilatant nor contractant, i.e. the specimen reaches a critical state. This was never observed in the CU-tests on kakirites (even after an axial strain of $4 \%$ ). The kakirites behave like an over-consolidated soil and some of the SB3.2 samples exhibited some softening after failure, which is typical for strong or moderately strong rocks, e.g. shale, schist and sandstone (ISRM 1978).

The dilatant behaviour of the kakirites in combination with their low hydraulic conductivity is favourable with respect to the deformations and stability of a tunnel close to the heading (short term behaviour). As the water content remains constant in the short term, negative excess pore pressures develop, which increase effective stresses and shear strength. This stabilizing effect does not exist in the case of breccias because their behaviour at failure is contractant.

\section{Practical Significance for Tunnelling}

The tunnelling-induced deformations depend on the mechanical properties of the ground, the initial stress, the initial pore pressure and the pressure exerted by the tunnel support. Time is another important factor; the response of a low-permeability, saturated ground to tunnelling is timedependent, because of the slow excess pore pressure dissipation over time (Terzaghi 1943). The short-term behaviour 

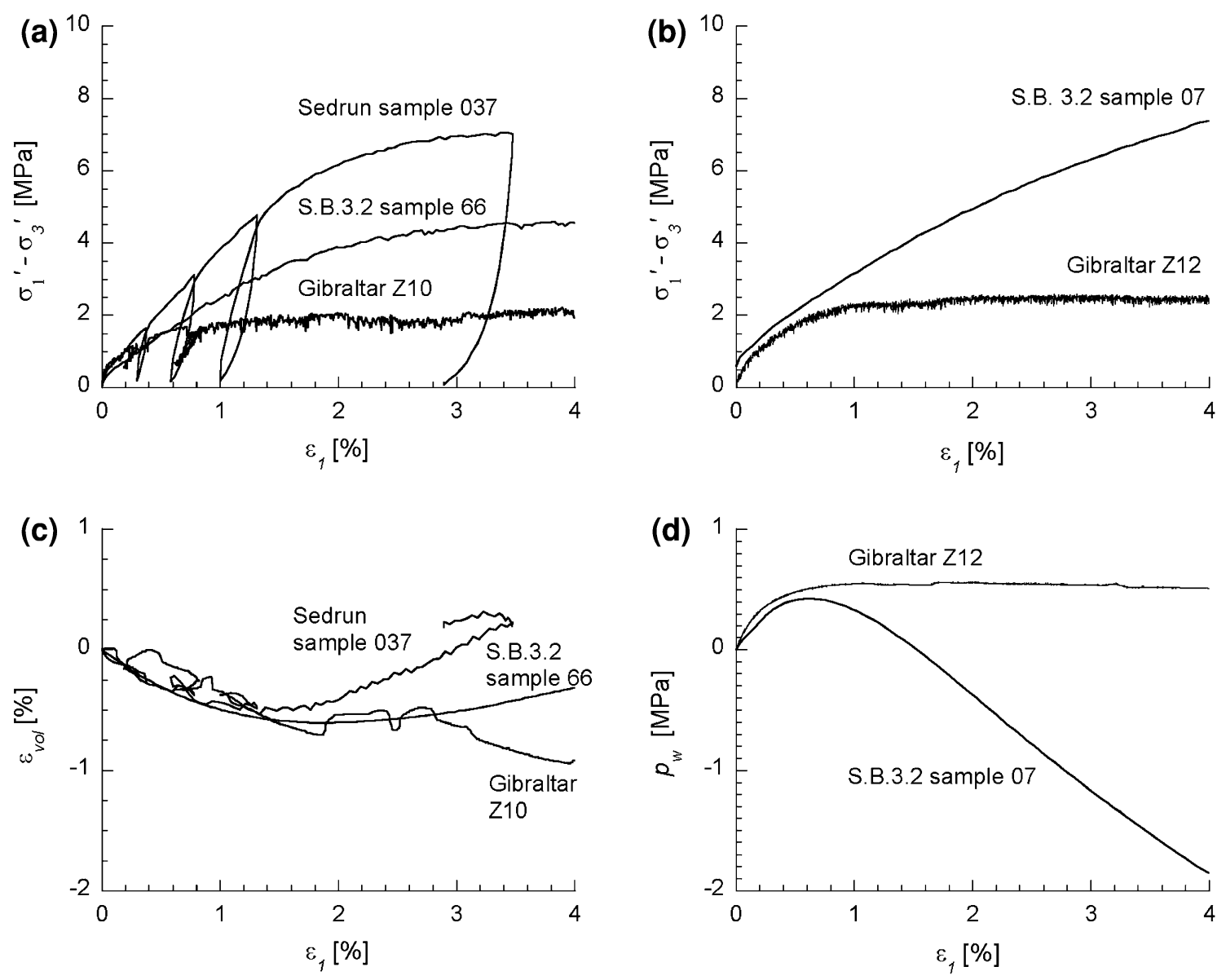

Fig. 21 Comparison of the behaviour of samples from Gibraltar, Gotthard (borehole SB 3.2) and Sedrun under approximately equal effective radial pressure (1.9, 1.5 and $2 \mathrm{MPa}$, respectively): a stress-

of the ground is important for tunnelling because it governs the ground-support interaction in the first stages after excavation close to the tunnel face. As usual in soil mechanics, we understand under "short-term" behaviour the instantaneous response to the excavation, i.e. the displacements that develop simultaneously as the tunnel advances under conditions of constant water content and zero volumetric strain.

Under the simplified assumptions of plane strain conditions and rotational symmetry (which are true for a deep cylindrical tunnel crossing a homogeneous and isotropic ground with a uniform and hydrostatic initial stress field), the relationship between tunnel wall displacement and support pressure is expressed by a single curve, the socalled "ground response curve" (GRC, Panet and Guenot 1982). The instantaneous deformations can be estimated by means of closed-form solutions, which have been derived for the familiar linearly elastic, perfectly plastic material model with the Mohr-Coulomb yield criterion. For incompressible ground constituents (the usual assumption for soils and weak rocks), Salençon (1969) developed a

strain curve in CD tests; $\mathbf{b}$ stress-strain curve in CU tests; $\mathbf{c}$ volumetric strain in $\mathrm{CD}$ tests; $\mathbf{d}$ excess pore pressure in $\mathrm{CU}$ tests

simplified classic solution that has been utilized by various authors (Graziani and Ribacchi 2001; Mair and Taylor 1993; Anagnostou 2009). Assuming non-dilatant plastic behaviour, which is reasonable for the Gibraltar breccias, the tunnel wall displacement

$u_{\mathrm{a}}=\frac{1+v}{E} a s_{\mathrm{u}} \mathrm{e}^{\frac{\sigma_{0}-\sigma_{\mathrm{a}}}{s_{\mathrm{u}}}-1}$,

where $a, \sigma_{0}$ and $\sigma_{\mathrm{a}}$ denote the tunnel radius, the initial total stress and the support pressure, respectively, while

$s_{\mathrm{u}}=\sigma_{0}^{\prime} \sin \phi^{\prime}+c^{\prime} \cos \phi^{\prime}$,

where $\sigma_{0}^{\prime}$ is the initial effective stress (Anagnostou 2009). $s_{\mathrm{u}}$ is the undrained shear strength for the problem under consideration. Equation (7) applies if the ground is overstressed, which is true if the support pressure $\sigma_{\mathrm{a}} \leq$ $\sigma_{0}-s_{\mathrm{u}}$. If this is not the case, the stresses remain within the elastic domain and $u_{\mathrm{a}}$ is given by Kirsch's solution:

$u_{\mathrm{a}}=\frac{1+v}{E} a\left(\sigma_{0}-\sigma_{\mathrm{a}}\right)$. 


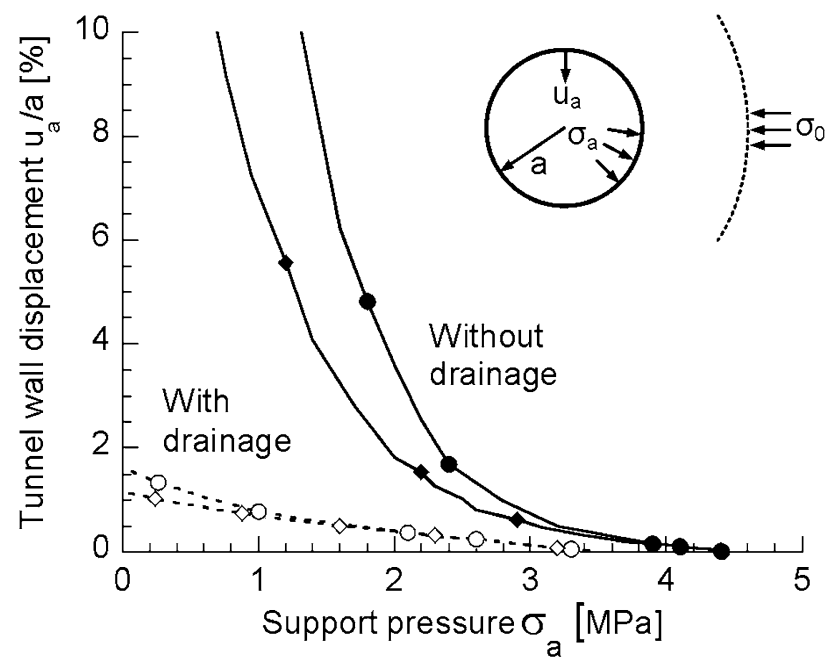

Fig. 22 Short-term ground response curve in the upper breccia zone with and without advance drainage (parameters: Table 5, set 1 and 2)

Table 5 Computational parameters

\begin{tabular}{lllllr}
\hline Parameter set $^{\mathrm{a}}$ & $\begin{array}{l}\sigma_{0} \\
(\mathrm{MPa})\end{array}$ & $\begin{array}{l}p_{\mathrm{w}, 0} \\
(\mathrm{MPa})\end{array}$ & $\begin{array}{l}E \\
(\mathrm{MPa})\end{array}$ & $\begin{array}{l}c^{\prime} \\
(\mathrm{MPa})\end{array}$ & $\begin{array}{l}\phi^{\prime} \\
\left.{ }^{\circ}\right)\end{array}$ \\
\hline 1 Upper zone min. values & 4.5 & 3.5 & 500 & 0.263 & 20.1 \\
2 Upper zone max. values & & & 500 & 0.375 & 26.0 \\
\hline 3 Lower zone min. values & \multirow{2}{*}{8.0} & 5.0 & 300 & 0.611 & 7.1 \\
4 Lower zone max. values & & & 300 & 0.376 & 14.3
\end{tabular}

${ }^{a}$ All parameter sets: $\psi=0^{\circ}, v=0.3$

Equations (7) and (9) will be used here to calculate the short-term response curves of the Gibraltar breccias for the range of measured strength parameters under Sect. 4.1. In addition, we will investigate the favourable effects of advance drainage on ground response. Advance drainage is in fact one of the auxiliary measures foreseen for the construction of the Gibraltar tunnel (Floria et al. 2008; Lombardi et al. 2009). It improves the tunnelling behaviour of the ground considerably, because the pore pressure relief increases the effective stresses and thus the undrained shear resistance (cf. Eq. 8). As shown by Anagnostou (2009), the effects of advanced drainage can be estimated by taking into account the drainage-induced modification to the initial stress field in the ground response equations (7) and (9): the total and the effective stress prevailing after advanced drainage (but before excavation) read as follows:

$\sigma_{\mathrm{a}, \mathrm{DR}}^{\prime}=\sigma_{0}^{\prime}+\frac{p_{\mathrm{w} 0}}{2(1-v)}$,

$\sigma_{\mathrm{a}, \mathrm{DR}}=\sigma_{0}-p_{\mathrm{w}, 0} \frac{1-2 v}{2(1-v)}$,

where $p_{\mathrm{w}, 0}$ is the initial pore pressure.
Note that the adopted material model (linearly elastic, perfectly plastic with Mohr-Coulomb yield criterion) cannot map some aspects of the observed behaviour of breccias in triaxial testing (e.g. the non-linearity of the stress-strain relationship right from the start of the loading or the contractant/dilatant plastic flow before failure). In the present case, the Young's modulus was taken based upon the initial stiffness of samples in CU tests (which have similar conditions as the short-term response), while the dilatancy angle $\psi$ was taken equal to $0^{\circ}$ (no plastic volumetric strain during shearing). The other parameters can be found in Table 2 .

Figure 22 shows the response curves of the breccias from the upper zone of the paleo-channels. The two solid curves illustrate the case where there is no advance drainage and bound the range of GRCs for the measured shear strength parameters (see Table 5 for the complete parameter set). The two dashed curves illustrate the case where there is advance drainage. The diagram shows a convergence range of only $0-10 \%$ because the mathematical derivations become inaccurate at higher values (the infinitesimal strain assumption). According to Fig. 22, the ground pressure is considerable (0.6-1.35 MPa depending on the strength) even after a $10 \%$ convergence. The important effect of advance drainage is evident: convergence will amount to just $2 \%$ even without any support. Similar conclusions can be drawn for the lower zone, the difference being that here the ground pressure and deformation are considerably higher (Fig. 23). Nevertheless, the results indicate that advance drainage in combination with a heavy support represents a viable construction option, provided that a sufficient time period is foreseen for the drainage work. These conclusions confirm the numerical results of Floria et al. (2008) and Amberg (2009) concerning the effects of drainage, and support the basic design considerations (Russo et al. 2008; Lombardi et al. 2009; Panciera et al. 2010).

It should be noted that the practically non-dilatant behaviour of the breccias accentuates their adverse response to tunnel excavation. As shown by Vogelhuber (2007), dilatancy is generally favourable in terms of undrained behaviour because it causes negative excess pore pressures, which increase the effective stress and thus the resistance to shear. The short-term GRC of dilatant materials can be calculated by modifying the closed solution of Salençon (1969). The derivation can be found in Vogelhuber (2007). Figure 24 shows response curves for the parameter set 2 of Table 5, dilatancy angles $\psi$ of $0^{\circ}-10^{\circ}$ with and without advance drainage. The results show that dilatancy really is favourable and that without advance drainage the ground response will be very sensitive with respect to the dilatancy angle. (In the case where there is 


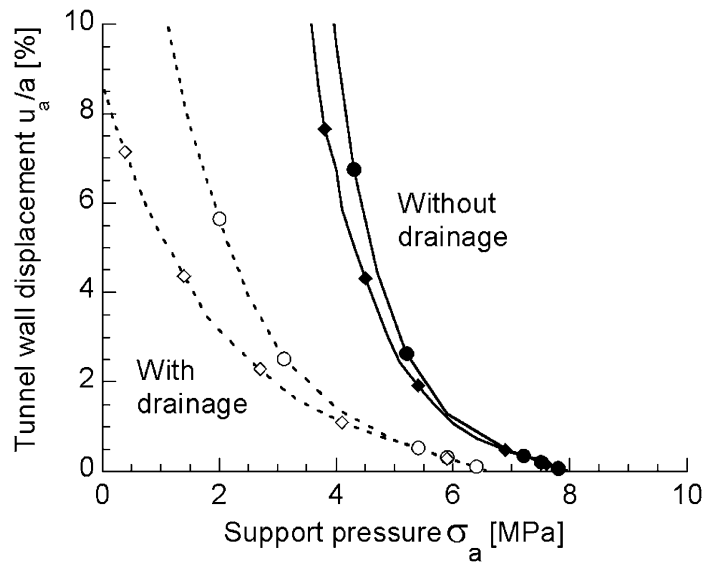

Fig. 23 Short-term ground response curve in the lower breccia zone with and without advance drainage (parameters: Table 5, set 3 and 4)

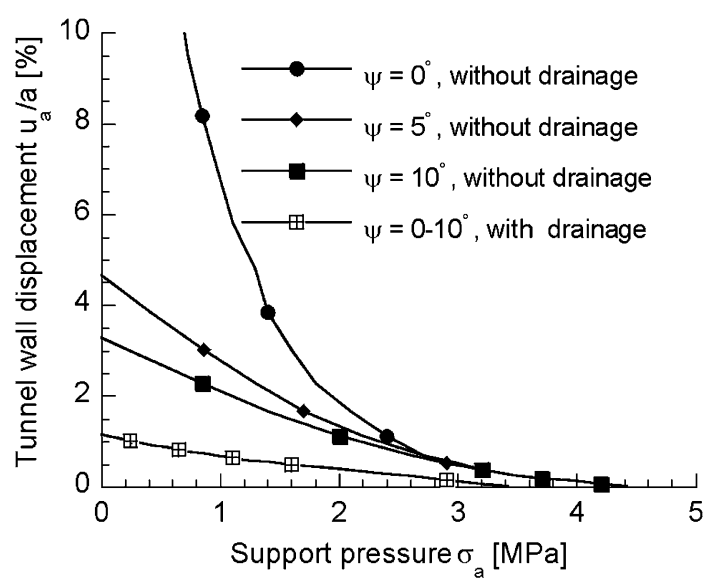

Fig. 24 Short-term ground response curve for dilatancy angles $\psi=0^{\circ}, 5^{\circ}$ or $10^{\circ}$ with and without advance drainage (other parameters: Table 5, set 2)

advance drainage, the influence of dilatancy will be very small.)

In conclusion, the results presented above indicate that tunnel construction through the breccias will be demanding. There are three main reasons for the expected heavy squeezing: low shear strength, high initial pore pressure and non-dilatant behaviour.

\section{Conclusions}

The Gibraltar Strait breccia consists of a soft, low-strength and extremely low-permeability clayey matrix containing hard inclusions. This, in combination with the high in situ total stress and pore pressure, makes triaxial testing very demanding and time-consuming. The laboratory investigations have underlined the importance of temperature control and of measuring the main variables (specimen deformations and axial stress) with redundancy and as close as geometrically possible to the specimen.

Our investigations show that the breccias can be classified as a stiff clay or a weak rock and that they resemble a normally consolidated or slightly over-consolidated material. The shear strength parameters of the breccias depend significantly on the depth. Their volumetric behaviour is mainly contractant before failure, but reaches a critical state after some shearing (constant peak stress and volumetric strain).

The importance of the breccias' properties from a tunnelling perspective was investigated in relation to their short-term GRC. The computational results underlined the importance of constitutive behaviour and confirmed the results of existing design studies inasmuch as they indicate that the breccias will already exhibit heavily squeezing behaviour in the vicinity of the tunnel face, but that this behaviour can be improved considerably by advance drainage.

Acknowledgments The authors are very glad to thank SECEGSA and SNED for the permission to publish the test results and for allowing the presentation of Figs. 1 and 2. The authors also wish to express their gratitude to Mr. Roca and Mr. Sandoval from SECEGSA and Mr. Bensaid and Mr. Bahmad from SNED for their support for the research project. The research was funded by a Grant from the Swiss National Science Foundation (SNF Grant No. 200021-137888).

\section{Appendix: Calculation of Volumetric Strain and of Temperature Compensation}

Determination of Volumetric Strain without Temperature Compensation

The volumetric strain of the sample can be determined either via oil volume change or via water volume change. Adopting the common sign convention of mechanics (i.e. that expansion is positive), the oil-based volumetric strain of the sample

Table 6 Data for thermal error computations

\begin{tabular}{lll}
\hline & Oil & Water \\
\hline$D_{\mathrm{o}}, D_{\mathrm{w}}(\mathrm{mm})$ & 140 & 140 \\
$D_{\mathrm{p}}(\mathrm{mm})$ & 140 & N/A \\
$V_{\mathrm{o}}, V_{\mathrm{w}}\left(\mathrm{mm}^{3}\right)$ & $2 \times 10^{6}$ & $4 \times 10^{5}$ \\
$V_{\mathrm{s}}^{\mathrm{a}}\left(\mathrm{mm}^{3}\right)$ & $2 \times 10^{5}$ & $2 \times 10^{5}$ \\
$\alpha\left(/{ }^{\circ} \mathrm{C}\right)$ & $1.2 \times 10^{-3}$ & $2 \times 10^{-4}$ \\
$\varepsilon_{\text {vol }}^{\text {err }}(\%)$ & 1.20 & -0.04 \\
\hline
\end{tabular}

${ }^{\mathrm{a}}$ For samples with a slenderness ratio $H / D=1$ 
$\varepsilon_{\mathrm{vol}}^{\mathrm{o}}=\frac{\pi\left(-D_{\mathrm{o}}^{2} \cdot \Delta h_{\mathrm{o}}-D_{\mathrm{p}}^{2} \cdot \Delta h_{\mathrm{p}}\right)}{4 \cdot V_{\mathrm{s}}}$,

where $D_{\mathrm{o}}, \Delta h_{\mathrm{o}}, D_{\mathrm{p}}$ and $\Delta h_{\mathrm{p}}$ denote the diameter and the displacement of the cylinder of the oil pressure amplifier and of the axial loading piston, respectively (Fig. 6; Table 6), and $V_{\mathrm{s}}$ is the volume of the sample. Analogously, the water-based volumetric strain

$\varepsilon_{\mathrm{vol}}^{\mathrm{w}}=\frac{\pi \cdot\left(D_{\mathrm{w}}^{2} \cdot \Delta h_{\mathrm{w}}\right)}{4 \cdot V_{\mathrm{s}}}$,

where $D_{\mathrm{w}}$ and $\Delta h_{\mathrm{w}}$ are, respectively, the diameter and the displacement of the pore water pressure device cylinder (Fig. 6; Table 6).

\section{Displacements due to Thermal Expansion of Oil and Water}

Since the volumetric expansion coefficient of metal is lower by several orders of magnitude than that of oil and water, the influence of thermal metal strain can be neglected. An increase in the fluid temperature by $\Delta T$ will cause an increase in the fluid volume, which manifests itself as a displacement of the oil pressure amplifier cylinder $\left(\Delta h_{\mathrm{o}}^{\text {temp }}\right)$ or of the pore water pressure device $\left(\Delta h_{\mathrm{w}}^{\mathrm{temp}}\right)$ :

$\Delta h_{\mathrm{o}}^{\mathrm{temp}}=-\frac{4 \cdot \alpha_{\mathrm{o}} \cdot \Delta T \cdot V_{\mathrm{o}}}{\pi \cdot D_{\mathrm{o}}^{2}}$,

$\Delta h_{\mathrm{w}}^{\mathrm{temp}}=-\frac{4 \cdot \alpha_{\mathrm{w}} \cdot \Delta T \cdot V_{\mathrm{w}}}{\pi \cdot D_{\mathrm{w}}^{2}}$,

where $V_{\mathrm{o}}$ and $V_{\mathrm{w}}$ are the thermal expansion coefficients and the volumes of oil and water in the test system, respectively (Table 6).

\section{Temperature-Induced Error}

For determining the temperature-induced volumetric strain errors $\varepsilon_{\mathrm{vol}}^{\mathrm{o}, \mathrm{err}}$ and $\varepsilon_{\mathrm{vol}}^{\mathrm{w}, \text { err }}, \Delta h_{\mathrm{o}}^{\text {temp }}$ and $\Delta h_{\mathrm{w}}^{\text {temp }}$ from Eqs. (14) and (15) are introduced into Eqs. (12) and (13), respectively, considering no axial strain in the sample, i.e. $\Delta h_{\mathrm{p}}=0$ in Eq. (12):

$\varepsilon_{\mathrm{vol}}^{\mathrm{o}, \mathrm{err}}=\frac{\alpha_{\mathrm{o}} \cdot \Delta T \cdot V_{\mathrm{o}}}{V_{\mathrm{s}}}$,

$\varepsilon_{\mathrm{vol}}^{\mathrm{w}, \mathrm{err}}=-\frac{\alpha_{\mathrm{w}} \cdot \Delta T \cdot V_{\mathrm{w}}}{V_{\mathrm{s}}}$,

The corrected volumetric strains read as follows:

$\varepsilon_{\mathrm{vol}}^{\mathrm{o}, \mathrm{corr}}=\varepsilon_{\mathrm{vol}}^{\mathrm{o}}-\varepsilon_{\mathrm{vol}}^{\mathrm{o}, \mathrm{err}}$,

$\varepsilon_{\mathrm{vol}}^{\mathrm{w}, \text { corr }}=\varepsilon_{\mathrm{vol}}^{\mathrm{w}}-\varepsilon_{\mathrm{vol}}^{\mathrm{w}, \mathrm{err}}$,
The last row of Table 6 shows, for the purposes of comparison between water and oil, the volumetric strain errors caused by a temperature increase of $1{ }^{\circ} \mathrm{C}$. The measuring system is less sensitive to water dilation than oil dilation by a factor of 30 .

\section{References}

Amberg F (2009) Numerical simulations of tunnelling in soft rock under water pressure. In: EURO:TUN 2009, 2nd international conference on computational methods in tunnelling, Ruhr University Bochum, pp 353-360

Anagnostou G (2009) The effect of advance-drainage on the shortterm behaviour of squeezing rocks in tunnelling. In: International symposium on computational geomechanics, Juan-Les-Pins, France, pp 668-679

Anagnostou G, Pimentel E, Cantieni L (2008) AlpTransit Gotthard Basistunnel Teilabschnitt Sedrun, Felsmechanische Laborversuche Los 378 Schlussbericht., vol 080109. Inst. für Geotechnik, ETH Zürich

Aristorenas GV (1992) Time-dependent behavior of tunnels excavated in shale. Ph.D. thesis, Massachusetts Institute of Technology, Boston

Bahmad A (2008) Unpublished communication from April 8, 2008, SNED

Barla G, Barla M, Debernardi D (2010) New triaxial apparatus for rocks. Rock Mech Rock Eng 43(2):225-230

Bellwald P (1992) A contribution to the design of tunnels in argillaceous rock. Ph.D. thesis, Massachusetts Institute of Technology, Boston

Bishop AW, Henkel DJ (1957) The measurement of soil properties in the triaxial test, 2nd edn. E. Arnold, London

Bonini M, Barla G (2012) The Saint Martin La Porte access adit (Lyon-Turin Base Tunnel) revisited. Tunn Undergr Space Technol 30:38-54

Bonini M, Debernardi D, Barla M, Barla G (2009) The mechanical behaviour of clay shales and implications on the design of tunnels. Rock Mech Rock Eng 42(2):361-388

Chiu HK, Johnston IW, Donald IB (1983) Appropriate techniques for triaxial testing of saturated soft rock. Int J Rock Mech Min Sci 20(3):107-120

Floria V, Fidelibus C, Repetto L, Russo G (2008) Drainage and related increase of short-term strength of low permeability rock mass. In: AFTES, International Congress of Monaco, Monte Carlo, pp 281-284

Franklin JA, Hoeck E (1970) Developments in triaxial testing technique. Rock Mech Rock Eng 2(4):223-228

Graziani A, Ribacchi R (2001) Short- and long-term load conditions for tunnels in low permeability ground in the framework of the convergence-confinement method. In: Adachi I et al (eds) Modern tunneling science and technology, vol 1. Swets and Zeitlinger, Amsterdam, pp 83-88

Hashimoto K, Tanabe Y (1986) Construction of the Seikan undersea tunnel-II. Execution of the most difficult sections. Tunn Undergr Space Technol 1(3-4):373-379

Head K (1998) Manual of soil laboratory testing. Effective stress tests, vol 2. Pentech Press, New York

ISRM (1978) ISRM suggested method for quantitative description of discontinuities in rock masses. Int J Rock Mech Min Sci Geomech Abstr 15:319-368 
ISRM (1983) ISRM suggested methods for determining the strength of rock materials in triaxial compression. Int J Rock Mech Min Sci 20(6):283-290

Kovári K, Amberg F, Ehrbar H (2000) Mastering of squeezing rock in the Gotthard Base Tunnel. In: World tunnelling, pp 234-238

Lade PV, Hernandez SB (1977) Membrane penetration effects in undrained tests. J Geotech Eng Div 103(2):109-125

Lambe TW, Whitman RV (1969) Soil mechanics. Wiley, New York

Lombardi G, Neuenschwander M, Panciera A (2009) Gibraltar Tunnel Project update-the geomechanical challenges (Gibraltar Tunnel Projektaktualisierung-die geomechanischen Herausforderungen). Geomech Tunn 2(5):578-590

Luján M, Crespo-Blanc A, Comas M (2011) Morphology and structure of the Camarinal Sill from high-resolution bathymetry: evidence of fault zones in the Gibraltar Strait. Geo-Mar Lett 31:163-174

Mair R, Taylor R (1993) Predictions of clay behaviour around tunnels using plasticity solutions. In: Proceedings of the wroth memorial symposium, pp 449-462

Panciera A, Bensaid A, Roca F (2010) The Gibraltar tunnel: the design revision. In: World tunnel congress, Vancouver

Panet M, Guenot A (1982) Analysis of convergence behind the face of a tunnel. In: Tunnelling 82, Brighton, pp 197-204

Pliego JM (2005) Open session-the Gibraltar Strait tunnel. An overview of the study process. Tunn Undergr Space Technol 20(6):558-569

Rice JR (1975) On the stability of dilatant hardening for saturated rock masses. J Geophys Res 80(11):1531-1536

Russo G, Grasso P, Bensaid A (2008) A framework for the risk analysis of the Gibraltar strait railway-link tunnel. In: ITAAITES world tunnel congress, India, pp 1726-1735

Salençon J (1969) Contraction quasi-statique d'une cavite a symetrie spherique ou cylindrique dans un milieu elastoplastique. Annales des Ponts et Chaussées 4:231-236

Sandoval N, Roca F, Sauras JM (2011) Proyecto de túnel ferroviario a través del estrecho de Gibraltar. Aljaranda: Revista de Estudios Tarifeños (80):20-34

Schneider T (1997) Behandlung der Störzonen beim Projekt des Gotthard Basistunnels. Felsbau 6(97):489-495
Schofield A, Wroth P (1968) Critical state soil mechanics. McGrawHill, London

Skempton A (1954) The pore-pressure coefficients A and B. Geotechnique 4(4):143-147

Steiger RP, Leung PK (1991) Consolidated undrained triaxial test procedure for shales. In: The 32nd U.S. symposium on rock mechanics (USRMS), Norman, Oklahoma, pp 637-646

Taik M, Serrano JM (1991) A tunnel project under the straits of Gibraltar. Tunn Undergr Space Technol 6(3):319-323

Terzaghi K (1943) Theoretical soil mechanics. Wiley, New York

Triclot J, Rettighieri M, Barla G (2007) Large deformations in squeezing ground in the Saint-Martin La Porte gallery along the Lyon-Turin Base Tunnel. In: Barták J, Hrdina I, Romancov G, Zlámal $\mathrm{J}$ (eds) Underground space-the 4th dimension of metropolises. Taylor \& Francis Group, London

Vallejo LG, Ferrer M (2009) Geological engineering. Taylor and Francis, London

Villanueva A, Serrano JM (1986) Geological and geotechnical studies for the Gibraltar tunnel. Tunn Undergr Space Technol 1(3-4): 237-241

Vogelhuber M (2007) Der Einfluss des Porenwasserdrucks auf das mechanische Verhalten kakiritisierter Gesteine. Ph.D. thesis, ETH, Zurich

Vogelhuber M, Kovári K (1998) Triaxialversuche im Labor, Sondierbohrung SB 3.2, AlpTransit-Gotthard Basistunnel. Institut fur Geotechnik, ETH Zurich

Vogelhuber M, Kovári K (2000) Triaxialversuche im Labor, Sondierbohrung SB 3.2, AlpTransit-Gotthard Basistunnel. Institut fur Geotechnik, ETH Zurich

Vogelhuber M, Anagnostou G, Kovári K (2004a) The influence of pore water pressure on the mechanical behavior of squeezing rock. In: Ohnishi Y, Aoki K (eds) 3rd Asian rock mechanics symposium, Kyoto, pp 659-664

Vogelhuber M, Anagnostou G, Kovári K (2004b) Pore water pressure and seepage flow effects in squeezing ground. In: Proc. X MIR conference "Caratterizzazione degli ammassi rocclosi nella progettazione geotechnica", Torino 